\title{
Seismic indicators of focused fluid flow and cross-evaporitic seepage in the Eastern Mediterranean
}

\author{
C. Bertoni ${ }^{1}$, C. Kirkham ${ }^{1}$, J. Cartwright ${ }^{1}$, N. Hodgson ${ }^{2}$, K. Rodriguez ${ }^{2}$ \\ ${ }^{1}$ Earth Sciences Department, University of Oxford, South Parks Road, Oxford, OX1 3 AN \\ ${ }^{2}$ SpectrumGeo Ltd. Dukes Court, Duke Street, Woking, Surrey, GU21 5BH
}

\section{ABSTRACT}

We present for the first time a synthesis of the evidence of focused fluid flow in the Eastern Mediterranean, providing an updated record that includes recent and past occurrences through the last ca. 6 My of evolution of the basin. We do this by adding the interpretation of a previously unpublished regional $2 \mathrm{D}$ seismic dataset to the existing occurrences of focused fluid flow reported in the literature. Our interpretation shows a high number (141) of focused fluid flow features, which span the stratigraphic interval from late Miocene to Recent. Of these features, (82) are at the seabed, and (59) are buried. The previous published record is more difficult to quantify, but in comparison shows an overwhelming majority of seabed features, with only rare examples of buried features.

The spectrum of the buried and seabed features covers pockmarks, pipes, mud volcanoes, clastic intrusions and collapse structures. Clustering of the fluid flow features is observed at different times in specific areas, including the Nile Cone, and the Levant, Herodotus, Cyprus and Latakia basins. With the buried record, we are able to highlight the evolution of the leakage points through time. Focused fluid flow venting has been occurring since the onset of the Messinian Salinity Crisis and the start of basinwide deposition of evaporites. We focus in particular on seismic indicators of leakage through evaporites, and of sub-evaporitic source for fluids and remobilized sediments. We also discuss the role of the evaporites as a seal to ascending fluids, and in which circumstances they can be breached.

Fluids (and associated remobilised sediments) are sourced from different intervals, from the sub- and supra-evaporitic section, and possibly within the evaporites. Only a minor 
proportion of the fluid flow features are certainly sourced from below the Messinian evaporites, and most of them are located in the Nile-Levant-Eratosthenes areas. The few examples of pathways that are able to cross thick, undeformed and well preserved evaporites are typically correlated to overpressure release and hydrofracturing. This confirms that the evaporites do act regionally as a very good seal as expected, while fluids are able to cross the evaporites only in their most extreme expression, i.e. in nearlithostathic overpressure conditions. This is confirmed by our observations made in the Eastern Mediterranean, where in the presence of relatively undisturbed evaporites, crossevaporite vertical fluid pathways are only observed at the high end of the flux-pressure range, and involve sediment remobilisation. Maps combining these different elements can be used to detect areas potentially more prone to breaching.

\section{KEYWORDS}

Focused fluid flow, Eastern Mediterranean; Evaporite leakage, Cross-evaporite seepage; Vertical fluid pathways; Seismic interpretation, Messinian, Buried fluid flow features.

\section{INTRODUCTION}

Focused release of pore fluids on the seabed of the Eastern Mediterranean has been widely documented over the past 30 years (Aloisi et al., 2000; Camerlenghi et al., 1992; Charlou et al., 2003; Cita, 2006; Cita et al., 1994; Dimitrov and Woodside, 2003; Dupré et al., 2010; Giresse et al., 2010; Hovland and Judd, 1988; Hübscher and Dümmong, 2011; Hübscher et al., 2009; Huguen et al., 2009; Judd and Hovland, 2007; Kopf et al., 1998; Kopf et al., 2000; Limonov et al., 1996; Loncke and Mascle, 2004; Lykousis et al., 2009; Maillard et al., 2011; Mascle et al., 2014; Moss et al., 2012; Praeg et al., 2014; Robertson et al., 1996; Robertson, 1998; Schattner et al., 2012; Woodside et al., 1997, 1998). The wide range of geological features that are used as indicators of this phenomenon are termed seepage, venting or focused fluid flow, and they are the product of nearly instantaneous, highly vertical 
and relatively fast release of basin fluids and sediments (see e.g. reviews by Andresen, 2012 and Cartwright et al., 2007). In this paper, we use the more generic term 'focused fluid flow' as it encompasses both intrusive and extrusive features, and seafloor seepage. The presence of widespread fluid flow features can indicate the predominance of a vertical vs lateral (carrier-bed driven) migration style, which is particularly important for understanding petroleum systems and play fairways (Demaison and Huizinga, 1991). If fluid flow is associated to overpressure release, it can provide an indication of large-scale processes that act to destabilise the pressure regime in the basin, and can help identify areas prone to paleo- or active overpressure venting (Andresen, 2012; Cartwright et al., 2007; Cartwright and Santamarina, 2015; Moss et al., 2012)

The recorded evidence of past (subsurface) focused fluid flow in marine settings is comparatively less frequent, due to the spatial extent of most of the fluid flow features, which are at the limit of the resolution of most commonly available seismic data. In recent years, a number of studies highlighted past events of focused fluid release in the Eastern Mediterranean, spanning the interval from the late Miocene onwards (Bertoni et al., 2013; Eruteya et al., 2015; Lazar et al., 2012; Reiche et al., 2014; Reiche et al., 2015). The presence of a large halite-dominated evaporitic body of Messinian (late Miocene) age had a large influence on the distribution of pore fluids and pressures in the Eastern Mediterranean. Evaporites, and in particular halite, possess excellent intrinsic sealing properties (Downey, 1984; Gluyas and Swarbrick, 2009; Hunt, 1990). The rapid sedimentation rates of halite can quickly form a tight seal and retard or inhibit compaction-led dewatering, leading to overpressure build-up: many of the world's largest oil and gas fields are sealed by evaporites (Warren, 2016). The Zohr discovery in the Eastern Mediterranean has been recently added to this list (Bertello et al., 2016; Esestime et al., 2016).

However, as recently highlighted in a comprehensive worldwide review of case studies (Warren, 2016), there are exceptional situations where leakage happens across salt units; recognising these cases is important not only for understanding seal risk in hydrocarbon exploration, but also for underground storage of waste or gas. The main factors that control 
salt leakage are: lithological heterogeneities within the evaporites (Anderson and Kirkland, 1980; Schoenherr et al., 2007); dissolution (Anderson, 1981; Anderson and Kirkland, 1980; Kastens and Spiess, 1984), high overpressures and hydrofracturing (Davison, 2009; Kukla et al., 2011), deep burial (Ghanbarzadeh et al., 2015; Schoenherr et al., 2007), presence of diapirs and welds (Warren, 2006). Intrusive magmatic bodies and hydrothermal activity also are factors contributing to salt breach (Schofield et al., 2014) and even lead to the precipitation of large masses of salt in deep basins (Hovland et al., 2006; Scribano et al., 2017). It is interesting to note that as a rule of thumb, a good seal can be provided by halite as thin as $2 \mathrm{~m}$, this value increases to $10 \mathrm{~m}$ if the salt is not pure halite (Warren, 2016). Therefore, with the exception of highly thinned evaporitic sequences and the creation of welds, in very thick, basinal evaporitic sequences, the thickness of the salt is not an important factor contributing to its breaching potential.

Examples of cross-evaporite seepage have been recorded in the Eastern Mediterranean (Bertoni and Cartwright, 2015), in extreme cases even where the evaporites are a few kmthick (Eruteya et al., 2015; Gradmann et al., 2005; Kirkham et al., 2017b; Reiche et al., 2014). However, we still lack a comprehensive study in the region that discusses how extensive evaporite breaching is at present, and was in the past. In this context, the subsurface record of cross-evaporite fluid flow features is particularly important, in order to reconstruct the pore fluids history of the basin through its different evolution stages.

We aim to contribute to this open debate by providing an integration of the evidence of fluid flow features in the Eastern Mediterranean, through the analysis of their distribution, timing, and potentially associated sub-evaporite water and petroleum source systems. We map the fluid flow features on a regional grid of $2 \mathrm{D}$ seismic data (Fig. 1) and build on previous studies in the various sub-basins of the Eastern Mediterranean, and on the more regionally extensive works by Hovland and Judd (2007) and Mascle et al. (2014). These previous works are focused on the recent and shallow record. In this study, we focus on the interpretation of focused fluid flow evidence that is identifiable using a widely spaced grid of 2D seismic reflection data. On this limited sample we are able to identify a large number of 
fluid flow features, some of which are buried and have a sub-evaporitic source; we therefore expect that through future availability of higher resolution and $3 D$ coverage data, it will be possible to discover many more of such examples. We describe the evidence concentrating on three main characteristics exhibited on seismic sections, i.e. their root zone or source, conduit, and upper terminus. These characteristics are important for the interpretation of the specific type of fluid flow feature, and provide indications of timing, process and source of the focused fluid flow release event (Kirkham et al., 2017a). This analysis is aimed at identifying both recent and past cross-evaporitic fluid flow and at comparing this record with that of supra-evaporitic features.

The structural setting of the area is diverse, with a relatively uniform passive margin (Levant Basin and Nile Cone) a subduction zone (Cyprus and Latakia basins) and strike-slip system (Dead Sea, Levant Fracture Zone). The entire Eastern Mediterranean Basin has also experienced fast changes of sediment and water loading and unloading in the last few million years; the balance of erosion and deposition has changed in the area through time, from low to exceptionally fast depositional rates, accompanied by intense erosional phases (Dolson et al., 2005; Macgregor, 2012; Roveri et al., 2014). In particular, the Messinian evaporites deposited in a time interval ranging from ca. 50 to $650 \mathrm{ky}$, according to the different hypotheses. Therefore, a ca. $2 \mathrm{~km}$ thick sequence of evaporites, such as observed in the Eastern Mediterranean (Lofi et al., 2011), could have been deposited at a rate between 3-4 $\mathrm{m}$ to $40 \mathrm{~m} / \mathrm{ky}$, i.e. within the ranges of current evaporitic systems (Reading, 1996), which is considerably faster than the Oligo-Miocene and Plio-Quaternary siliciclastic deposition in the deep Eastern Mediterranean Basins. All these factors have the potential to prime the sub-evaporitic sequence to the creation of overpressures and their release in focused events. Our analysis leads to the identification of clusters of the focused fluid flow features in the different geodynamic and sedimentary domains, and points to the definition of areas that are prone to conveying the fluids in a discontinuous form rather than by standard continuous dewatering processes. Therefore, the key objectives of this paper are: 
- To provide an overview of deeply rooted focused fluid flow pathways, and highlight regional anomalous basin drainage patterns in the Eastern Mediterranean;

- To define seismic indicators of leakage through thick evaporites in the area;

- To discuss the role of the evaporites as a seal to ascending fluids, and in which circumstances they can be breached.

Ultimately, this has global implications for understanding the factors that control the occurrence and flux of cross-evaporitic fluid migration.

\section{GEOLOGICAL SETTING AND TECTONIC DOMAINS}

The study area covers a wide offshore geographical region in the Eastern Mediterranean, bordered by the island of Cyprus to the north, the Levant coastline to the east, the Nile Delta to the south, and the Mediterranean Ridge to the west-northwest (Fig.1). For the purposes of this study, the area is divided into a series of sub-basins: the Latakia, Cyprus (or Tartus), Levant, Herodotus Basins, and one isolated continental fragment, the so called 'Eratosthenes Seamount', also known as the Eratosthenes Block (termed used hereafter) or Platform (Bowman, 2011; Esestime et al., 2016; Garfunkel, 2004; Hübscher et al., 2009; Reiche et al., 2014; Robertson, 1998).

The study area is located at the interaction zone among the Eurasian, African and Arabian plates (Fig 1). The region is currently dominated by the collision between the African and Eurasian Plates and related subduction, with the Mediterranean Ridge representing its accretionary wedge (Aal et al., 2000; Camerlenghi and Cita, 1987; Huguen et al., 2001; Robertson and Kopf, 1998). The northern margins of the Levant Basin and the Eratosthenes Block are being subducted northwards while the African plate move north wards relative to the Eurasian plate at a rate of ca. $10 \mathrm{~mm} / \mathrm{y}$ (McClusky et al., 2000).

The basins covered in this study developed mainly during the Permo-Triassic during the rifting of the Neotethys Ocean, which resulted in the breaking off of Gondwana into several 
large continental fragments (Gardosh et al., 2010; Hawie et al., 2013). Rifting continued into the Mid-Jurassic with the separation of the Eratosthenes Block from the Arabian Plate (BenAvraham et al., 2006; Garfunkel, 2004; Hawie et al., 2013). The Herodotus and the Levant Basins developed as isolated depocentres to the west and east of the Eratosthenes (Fig. 1 and 2). Importantly, oceanic crust underlies the Herodotus and Cyprus Basins (Garfunkel, 1998) 1998). The nature of the Levant Basin substrate is still debated, although most authors concur that it is underlined by thinned continental crust (Gardosh and Tannenbaum, 2014).

The aftermath of the rifting led to the development of a passive continental margin that is currently preserved in the Levant, Eratosthenes and Nile regions, with a carbonate platform setting alternating with intra-platform basins and fluvio-deltaic deposits, dominating the area during most of the Jurassic and Cretaceous (Bein and Gvirtzman, 1977; Garfunkel, 1998; Garfunkel and Derin, 1984; Marlow, 2014; Robertson, 1998; Ziegler, 2001).

Since the Cretaceous, the tectonic plate reconfiguration led to three main tectonic events:

1. A regional compressional phase due to the collision of the African-Arabian with the Eurasian (Anatolian) plate, and closure of the Tethys Ocean. The Cyprus and Latakia Basins formed at this stage, after the emplacement of ophiolites along the Latakia Ridge system (Fig. 1 and 2) . Furthermore, the Syrian Arc folds developed onshore and in the Levant Basin (Gardosh and Druckman, 2006; Mart et al., 2005; Robertson and Dixon, 1984). The evolution of the Syrian Arc peaked during the Eocene, with the onset of continental collision on the Arabian margin, and has then continued into the late Tertiary and locally up to recent times.

2. The separation of the Arabian plate from the African plate along a system of strikeslip faults dating back to the Eocene or Oligocene (Nader, 2011). Within the strike-slip system, the Dead Sea Transform Fault was initiated during the Miocene (Hempton, 1987).

3. The convergent margin of the Cyprus Arc from the early Miocene (Maillard et al., 2011; Montadert et al., 2014). A change in motion at the end of the Miocene, led the regime to transition from compressional to dominantly strike-slip and resulted in large volume of 
sediment entering the Eastern Mediterranean via the Nile Delta and associated fan systems (Skiple et al., 2012).

The basin responded to these events shifting depocentres through time. Subsidence in the Oligocene created the deep Northern Levant Basin, which was filled with thick sequences of coarse clastic basin floor fan sediments supplied by the Nile Delta (Fig. 2) (Macgregor, 2012; Steinberg et al., 2011). The western area, still part of the Arabian and African continent, was affected by repeated uplift and generated a large platform area during the Late Oligocene-Early Miocene with dominantly carbonate deposition (e.g. in the Eratosthenes Block). Increased rates of erosion led to the development of canyons on the margin of the Levant basin, since the late Cretaceous (Buchbinder and Zilberman, 1997; Druckman et al., 1995). These canyons underwent alternating subaerial-submarine activity in different phases, acting as fairways for clastic sediments into the basin.

The deposition of a multi km-thick sequence of evaporites dominated the deep basins in Messinian times (Fig. 3). Contemporaneously, some parts of the Cyprus Basin and Eratosthenes Block, and the margins of the other basins, were subaerially exposed and eroded (Robertson, 1998). The re-establishment of open marine conditions resulted in the deposition, from the early Pliocene, of several major clastic systems in the Nile Delta, Herodotus Basin and in the Levant Basin (Frey-Martinez et al., 2007; Gardosh and Druckman, 2006). The sediments derived from these systems were distributed on the margins and basins as clastic wedges with maximum thickness generally located in the shelfal and slope areas: these constitute the overburden to the Messinian evaporites (Fig. 4). At present, the broader Levant Basin is located within an area of active transpressive tectonics (Skiple et al., 2012). Extensive salt diapirism is observed in the Latakia Basin, Herodotus Basin and part of the Nile Cone (Gaullier et al., 2000; Loncke et al., 2006; Maillard et al., 2011; Reiche et al., 2014) while the margins experienced gravitational sliding detaching within the evaporite unit (Aal et al., 2000; Allen et al., 2016; Cartwright and Jackson, 2008; Tibor and Ben-Avraham, 1992). 


\section{INTERPRETATION}

\subsection{Rationale}

In the study area, we interpreted a grid of 2D seismic data (Fig. 1) and implemented the results with published data in order to constrain the regional distribution of focused fluid flow features. The seismic database is composed of over $12000 \mathrm{~km}$ of 2D lines acquired in 2000 by Fugro-Geoteam, with streamer length of $7200 \mathrm{~m}$ and record length of $12 \mathrm{~s}$. The data were reprocessed in 2011 by SpectrumGeo using a conventional PSTM sequence.

Seismic evidence of fluid flow such as pipes, pockmarks and mud volcanoes is commonly identified on the seismic reflection data through the recognition of three specific diagnostic features: the root zone, the conduit and the upper terminus (Andresen, 2012; Cartwright and Santamarina, 2015; Judd and Hovland, 2007; Kirkham et al., 2017b). The root zone of the vertical fluid pathway is usually indicated by the deepest region where the deformation associated with the focused fluid flow is observed (Kirkham et al., 2017a). In fluid escape pipes, the root zone is identifiable as the first continuous reflection beneath the conduit vertical zone of disruption and discontinuity (Cartwright and Santamarina, 2015; Moss and Cartwright, 2010). The seismic response observed within a conduit is the result of the forceful intrusion of fluid and potentially, sediment. Therefore the absence of similar fluid related deformation within the root zone is exhibited as a contrastingly continuous and undisrupted reflection.

Correctly identifying the root zone may give an indication of the source and potentially the composition of the fluids (Moss and Cartwright, 2010). The stratigraphic interval hosting the root zone can be affected by sediment depletion, if the fluid flow feature involves sediment remobilisation, such as in mud volcanoes (Kirkham et al., 2017b; Stewart and Davies, 2006). The identification of the root zone can be particularly challenging in deeper features, where decrease in frequency and loss of resolution of the seismic data can constitute a potential imaging issue and generate seismic artefacts and spatial biasing. If the root zone is located across or below a thick evaporitic body the seismic resolution, and therefore imaging quality, 
decreases significantly due to the high velocity and low frequency observed in halite and other evaporitic minerals. Therefore, we maintained a conservative approach and interpreted only the unequivocally clear root zones of vertical fluid pathways that cross evaporitic bodies, i.e. the larger bypass features and the ones associated with deep-rooted faults and halokinesis.

The conduits of fluid flow features represent the connection between the source and their upper terminus. The conduits can extend vertically up to a few $\mathrm{km}$ (Moss et al., 2010) and provide important information on the mechanism of fluid transport. Similar to the root zone, conduits can present a challenge for interpretation, due to seismic imaging issues related to their subtle vertical and planform morphology. Their interpretation is therefore strongly dependent on the seismic characteristics of the hosting succession. As an example, pipe conduits hosted in highly continuous, parallel, and high frequency seismic reflections (such as in a hemipelagic depositional environment) are usually well imaged (Cartwright and Santamarina, 2015; Løseth et al., 2011), while a low-reflectivity and/or low frequency evaporitic series can hinder the visualization of such conduits (Kirkham et al., 2017a). Additionally, the interpretation of the lateral margins of the conduit strongly depends on the presence of anomalous amplitudes at or around the discontinuous and disrupted reflections identifying the conduit.

The upper terminus is the shallowest level at which the disruption associated with the fluid flow feature is observed, and it is linked with the point of piercement of the present or paleo seabed (e.g. pockmarks), or accumulation of intrusive and extrusive material (e.g. mud volcanoes). It also defines the point of maximum upper extent of a conduit. The upper terminus of the fluid conduits can reveal the age of the fluid expulsion. This is possible when the interplay of deposition and deformation are favourable to the preservation of the fluid expulsion record, e.g. when the fluid flow event had paleo-seabed expression (either of extrusive or intrusive nature) and syn-depositional geometries associated to it. These conditions are usually met in the case of formation of negative (e.g. pockmarks, calderas, collapse depressions) or positive (e.g. mounds, volcano edifices) relief structures at or near 
the seabed, and at a suitable seismic resolution. The accuracy of the dating of the fluid expulsion event depends on the quality and resolution of seismic data, so it is defined on a case by case basis.

Focused fluid flow evidence identified in this study is grouped and described based on two main criteria: 1) a geographic criterion, by their distribution in the basins within the Eastern Mediterranean, and 2) within the specific basin, a focus on the fluid flow features that have a deep, pre-evaporitic source.

\subsection{Levant region and Nile Deep Sea Fan}

A detailed analysis of the 2D seismic data shows evidence of a large number of fluidrelated features focused in the southern and central part of the Levant Basin, which is the main focus of this study (Fig. 1 and 2A). In the southern Levant Basin (Fig. 5), we observe narrow vertical zones of disruption and dimmed amplitudes interrupting the primary stratigraphic horizons. They terminate upwards with either a concave upwards or downwards morphology (Fig. 5). Their upper termini are mostly located on the seafloor, but for a few cases it is found in the subsurface, a few hundreds of meters deep. The narrow, vertical character of the disruption zone and its upper terminus allow their interpretation as conduits of fluid flow pipes.

The best example is observed in Figure 5B, where the character of the pipe is clearly distinguishable from the evaporite-cored anticlines. The limited lateral extent of the mound (ca. $1 \mathrm{~km}$ ) and the overall vertical discontinuous disruption of the reflections in its conduit (Fig. 5B) differ from the deformation related to the anticlines, which present a wavelength of ca. $5 \mathrm{~km}$, and regularly deformed, concave downwards continuous Pliocene-Quaternary reflections. This pipe appears to be spatially related to a strike slip fault that is clearly observed on the nearby 3D survey, although the feature itself is not covered by 3D data (Fig. 5C). In the region, the structural context of the evaporites and the post-evaporitic sediments

is dominated by the presence of strike-slip faulting (Clark and Cartwright, 2009). The 
observed spatial coincidence of the pipe with the faulting strongly suggests that the vertical fluid pathways are exploiting paths of structurally enhanced permeability. Breaks in continuity in the typically highly reflective and continuous intra-salt layers within this region of the Eastern Mediterranean (Bertoni and Cartwright, 2006; Feng et al., 2016) indicate that the pipe has transected the evaporites and is sub-evaporitic in source.

The presence of a mounded upper terminus shows that a positive mass balance is associated with these features, implying the emplacement of intruded or extruded sediments, or the precipitation of carbonate mounds on the seafloor. The lack of high reflectivity and amplitude character of the mound seem to support the first proposed genetic mechanism, i.e. by sediment remobilisation. Based on these interpretations, we can constrain the timing of pipe formation with a reasonable accuracy, from the most recent horizon that is deformed by the pipe, and this is located within the Quaternary stratigraphic section: this offers a first order constraint on the formation of the pipes. Higher detail in dating of the event horizon for these pipes is not attainable, due to the limitations of the longdistance well tie of the stratigraphic horizons, and the scarce biostratigraphic information available in published wells (Bertoni and Cartwright, 2005; Bertoni and Cartwright, 2006; Eruteya et al., 2015; Gardosh and Druckman, 2006).

In the northern part of the Levant Basin, where the Messinian evaporites are ca. $1.5 \mathrm{~km}$ thick, the base of the evaporites is characterised by concave upwards features, with relief of $200 \mathrm{~m}$ and lateral extent of ca. $400 \mathrm{~m}$ (Fig. 6A). Within this depression we observe an increase in evaporite thickness in unit T1 or ME1 (Bertoni and Cartwright, 2007; Feng et al., 2016), while the overlying intra-evaporitic units and the post-evaporitic unit show no evidence of associated deformation. This implies that the formation of the depression was prior to evaporite deposition. This particular feature is covered by $3 \mathrm{D}$ seismic data, and the planform morphology of this feature can be clearly identified as circular on the map showing the variance extraction of Horizon N, i.e. the base of the Messinian evaporites (Fig. 6B). The characteristics identified in section (concave morphology and truncation of reflections on its outer margins) and the circular planform show strong similarities with pockmarks. 
Base-evaporite pockmarks have been previously reported in the area (Bertoni et al., 2013; Lazar et al., 2012) and their timing of formation linked to the initial phases of the Messinian Salinity Crisis (MSC), where water unloading related to high-amplitude sea-level fluctuations may have been the cause for sudden overpressure release. Even a few $100 \mathrm{~s} \mathrm{~m}$ sea-level fall can affect subsurface pressure in fine-grained sediments (Hermanrud et al., 2013). Although amplitude of sea-level changes during the MSC is widely debated, ranging from 0 to 2000 m (Al-Balushi et al., 2016; Hsu", 1972; Rouchy and Caruso, 2006; Roveri et al., 2014; Roveri et al., 2016; Ryan, 2009), it is considered that a conservative estimate of a fall of at least 200 to $500 \mathrm{~m}$ is required to explain the subaerial exposure and erosion of the margins (see e.g. Roveri et al. 2016 and references therein).

Based on this analogy, we suggest that the crater observed in the Central Levant Basin was formed by fluid expulsion that pre-dates the deposition of the Messinian evaporites. Additionally, there is no indication of venting activity during or after evaporite deposition. The limited imaging in the region underlying the pockmarks does not allow the identification of an associated conduit and source. However, the stratigraphic location of this fluid flow feature at the base of the Messinian evaporites allow us to define it as sourced in the deep, subevaporitic sequence.

The observations of a diverse set of focused fluid flow features in this area are in accordance with those described in previous studies in the region. The Levant Basin hosts examples of fluid-driven dissolution collapse craters and intruded clastic mounds, both dated as Pliocene (Bertoni and Cartwright, 2005; Frey-Martinez et al., 2007; Fuhrmann et al., 2010). Further pockmark activity is recorded in the same basin at different intervals in the Pliocene and Quaternary (Eruteya et al., 2015; Lazar et al., 2016).

Seabed mud volcanoes have been also reported in the Southern Levant Basin, e.g. the Pauli mud volcano (Netzeband et al., 2006) and in the Northern Levant Basin (Reiche et al., 2014). In the Nile Deep Sea Fan, buried pockmarks have been interpreted at the base of the Messinian evaporites (Al-Balushi et al., 2016) are similar to the pockmarks observed in the Levant Basin (Lazar et al., 2012; Bertoni and Cartwright, 2013). Seabed pockmarks and mud 
volcanoes have been also reported and thoroughly described in previous studies in the area (Fig. 1) (Aloisi et al., 2000; Bayon et al., 2009; Charlou et al., 2003; Dupré et al., 2010; Giresse et al., 2010; Huguen et al., 2009; Kirkham et al., 2017b; Loncke et al., 2006; Loncke and Mascle, 2004; Lykousis et al., 2009; Mascle et al., 2014; Moss et al., 2012; Woodside et al., 1997).

Seabed sampling of the material extruded from the mud volcanoes has documented its provenance from a mix of deeply buried, pre-evaporitic sediments (mostly middle to late Miocene in age, but sporadically also upper Cretaceous to Eocene in age) (Giresse et al., 2010; Mascle et al., 2014), in a region where the Messinian evaporites are 100s of meters to few kilometres thick. The root zones of the mud volcano conduits indicate that their main source of sediment is located within the immediate pre-evaporitic package (Kirkham et al., 2017a). Fluids can be potentially sourced also from the supra-evaporitic interval, after conduit generation; however, sufficient fluids to liquefy mud within the sub-evaporitic interval must have been present for remobilisation and conduit formation. The presence of salt brines sampled over the seabed mud volcanoes suggests that the evaporites are involved in this process through percolation and remobilization of salt-bearing Messinian deposits (Huguen et al., 2009).

Shallow biogenic gas can also contribute to the fluid content (Bayon et al., 2009; Huguen et al., 2009; Prinzhofer and Deville, 2013). Recent studies have also demonstrated the prolonged activity of these mud volcanoes at different times during the Pliocene and Quaternary, and possibly in the late Miocene (Kirkham et al., 2017b), revealing an almost continuous, episodic release of fluids through the past ca. 6 My.

\subsection{Herodotus Basin and Eratosthenes Block}

The Herodotus Basin and Erathosthenes Block cover an extensive region located in the westernmost part of the study area, and immediately to the west of the Levant Basin (Fig. 1). Nearly all the focused fluid flow features interpreted in the region formed in recent times, at 
or near the seabed. The basin is strongly deformed by a very recent phase of salt tectonics. It is particularly challenging, therefore, to recognise buried vertical fluid pathways due to the disrupted seismic signal. Most of focused flow features in the area show a seabed or nearseabed expression: we describe two prominent examples that are analysed in detail, because their source is located underneath a thick Messinian evaporitic sequence (Fig. 7 and 8).

The first of these two features, observed at the margin of the Herodotus Basin, shows a clear seabed expression, and a rather complex buried structure (Fig. 7). This feature has a concave downwards seabed expression, and its subsurface geometry is characterised by lenses of reflections that are arranged at both sides of the central axis of the feature, and thin outwards. The overlying reflections terminate in onlap on the sloping side of the lenses. This morphology is strongly reminiscent of a Christmas tree type of geometry and is diagnostic of extrusive mud remobilisation that is typically observed in mud volcanoes (Deville et al., 2003). This mud volcano is located above a thick ( $>1 \mathrm{~km}$ ) sequence of evaporites, and overlain by ca. $800 \mathrm{~m}$ of Plio-Pleistocene, deep water clastic sediments. The Plio-Pleistocene sediments show no evidence of depletion, and the thickness of the reflection packages below the mud volcano does not reflect a negative mass balance. Therefore, the source of the mud volcano, and its root zone, are most likely located underneath the Plio-Quaternary sequence. The composition of the evaporite package in the region does not include large mud bodies (Feng et al., 2016). Therefore, the most likely source of sediment for the mud volcano is in the pre-evaporitic package, which includes fine grained clastics (unpublished well reports, Nile region), with the conduit of the mud volcano crossing the evaporites.

The second prominent fluid flow feature is observed at the margins of the Eratosthenes Continental Block (Fig. 8). This feature is characterised by a series of localised amplified reflections below the seabed, arranged as lateral fringes around a main subvertical axis, and these fringes interdigitate with the primary stratigraphic reflections (Fig. 8). This geometry is reminiscent of a pipe or chimney that exhibits evidence of clastic intrusion. The amplitude 
anomalies overlie a subvertical disruption zone with dimmed amplitudes. The feature is located directly above a locally thinned evaporitic series, and at a distance of a few kilometres from the lateral pinch-out of the evaporites. The feature also directly overlies a deep, sub-evaporitic crest, which displays a reflection configuration characterised by truncation, and lateral onlap (Fig. 8B), resembling pinnacle reefs and small carbonate platforms. Such depositional bodies have been previously observed in nearby areas of the Levant Basin (Bertello et al., 2016; Esestime et al., 2016; Sagy et al., 2015) and have been attributed to sub-evaporite carbonate highs that widely developed in the region from the late Cretaceous to the Eocene and, at the fringes of the Eratosthenes Block, to the Miocene. The strong spatial coincidence of the pipe with the structural high suggests a deep crestal control of the fluid/sediment source and a typical focusing mechanism for the genesis of the fluid venting.

The two fluid flow features described in the proximity of the Eratosthenes Block are rare examples of the record of such events in the wider area, covering also the eastern part of the Herodotus Basin. The westernmost area is instead characterised by the highly dense mud-volcano province bordering the Mediterranean Ridge (Kopf et al., 1998; Kopf et al., 2000). The other fluid flow features described in the Eratosthenes region include a seabed pockmark field, which is associated to a system of faults (Judd and Hovland, 2007). Additionally, previous studies report the presence of flat spots and gas chimneys in the postevaporitic sequences of the Herodotus Basin (Montadert et al., 2014). The amplitude anomalies are single or stacked events spanning from the early Pliocene to the nearseabed. According to these authors, the occurrence of these amplitude anomalies documents the presence of gas of probable biogenic origin in these sediments, and a related shallow plumbing system (Montadert et al., 2014).

\subsection{Cyprus and Latakia Basin}


The Cyprus Basin is bordered by the Latakia Ridge to the south, the Larnaca Ridge to the north, by the Cyprus Island to the west and by the Eastern Mediterranean coastline to the east (Fig. 1 and 2B). Evaporite distribution in this area is strongly influenced by the Miocene to Recent structural development (Fig. 3). The thickness of the evaporites is reduced in comparison with the deeper Levant and Nile areas, and it is on average $400-500 \mathrm{~ms}$ (Fig. 3), corresponding to ca. $900-1100 \mathrm{~m}$ using the seismic velocity typical of the evaporite unit in the area (Kirkham et al., 2017b). The pinch-out and lateral margins of the evaporites are mostly controlled by the tectonic structures originated by the plate tectonic convergence in the area.

An excellent example of a buried fluid flow feature is observed in this part of the study area (Fig. 9). On seismic section, the reflections immediately overlying the Messinian evaporites are locally affected by a decrease in continuity and a triangular, convex upwards geometry (Fig. 9). This km-scale feature directly overlies a convex downwards deflection at the top of the evaporites (TES, Top Erosional Surface). Despite the ease of interpretation of the upper and basal surfaces of this feature, its lateral margins are challenging to constrain. The evaporites thin from $300 \mathrm{~ms}$ to $<50 \mathrm{~ms}$ directly below this feature; this thinning has been evaluated considering the geometry of the base evaporites reflector once the push-down effect has been removed. The sub-salt imaging of this feature is limited. However the geometry of the base Miocene-Oligocene reflections suggests the presence of a structural high, broadly underlying the described feature, in a slightly offset crestal position. Based on stratigraphic position, timing of emplacement, reflection geometry and internal seismic facies of the feature, and by analogy with the features described in the Levant area, we interpret this feature as an intrusive body similar to the clastic intrusions previously described in the southern Levant basin (Frey-Martinez et al., 2007; Fuhrmann et al., 2010).

The edifice sits directly on top of the evaporites, suggesting that the source for sediments is located within or below the evaporites. The acoustic transition between the infill of the intrusion and the underlying evaporites is a hard, high amplitude reflection, therefore eliminating the possibility that it is comprised of evaporites (Fig. 9). This observation, 
together with the published data on internal evaporite composition, which does not account for large accumulations of siliciclastic sediment (Feng et al., 2016), points to a source of remobilised sediments located in the pre-evaporitic siliciclastic sequences. This clastic intrusion is particularly important therefore, as an example of cross-evaporitic fluid flow and sediment mobilisation. Another feature interpreted as a clastic intrusive mound is observed in the central part of the Cyprus basin (Fig. 10) and it is located in a similar stratigraphic position in the seismic reflectors immediately overlying the Messinian Erosional Surface (MES), i.e. where thin, sub-seismic resolution evaporitic deposits are present.

The potential role of the evaporites in creating a lateral drainage system by conveying sub-evaporitic migrating fluids along the regional dip of the base of the evaporites, up to their transition to the Messinian Erosional Surface, is indicated by vertical fluid pathways that are rooted at the pinch-out of the evaporites. An example is shown by stacked concave upwards reflections in the Pliocene to Recent section, which form a vertical conduit overlying a positive feature just above the MES (Fig. 10). The positive relief at Horizon MES propagates at depth in the sub-evaporitic reflections. This feature is interpreted as a pipe that developed above a sub-evaporitic crest, and is possibly mediated by a fault forming a bypass route for ascending fluids.

The examples presented complement the previously published research on sediment remobilisation and collapse structures, described in the Cyprus basin (Hübscher et al., 2009; Maillard et al., 2011). Those previous studies describe large depletion zones at the top of the evaporites, and in some cases, salt welds that are interpreted as pathways for sub-evaporitic fluids. Overall, the evidence collected here suggests that in the Cyprus Basin, sub-evaporitic fluids are able to migrate vertically across the evaporites, mostly in the past record (late Pliocene-early Quaternary) and laterally along the base of the evaporites and up to the seabed in more recent times, through windows (welds, depletion craters) in the evaporites.

Previous studies in the Latakia Basin, to the north of the Cyprus basin, show little evidence of focused fluid flow features with cross-evaporite conduits and sub-evaporitic source. These studies suggest that large sub-evaporitic structural highs could be the source 
of hydrocarbon gas migrating through a thinned evaporitic series and emplaced into Pliocene-Quaternary sediments (Bowman, 2011). In general, the lack of clear examples of cross evaporitic fluid flow could be ascribed to the overprint of salt tectonics deformation, both in terms of limited sub-salt imaging, and on the creation of effective pathways for continuous and large scale lateral and vertical dissipation of fluids. An alternative explanation is that there are very few examples which are also not intersected by the coarse 2D seismic grid available here. This might be indicating a highly competent seal or the absence of sub-evaporitic high pore fluid pressures.

\subsection{Synthesis of fluid plumbing systems}

In this study, we have identified a high number (141) of focused fluid flow features, which span the stratigraphic interval from late Miocene to Recent. Of these features, (82) are at the seabed, and (59) are buried. The previous published record is more difficult to quantify, but in comparison shows an overwhelming majority of seabed features, with only rare examples of buried features.

Here we focus in particular to the features that show a cross-evaporitic conduit and/or a sub-evaporitic source; these features have been described in detail, and their main characteristics are summarised in Figure 11. Combining all the previous observations, we present a schematic model for the Eastern Mediterranean fluid plumbing systems (Fig. 12). We use the term 'fluid' instead of 'hydrocarbon plumbing system', with the aim to extend its original use developed in a petroleum exploration context, to describe the pathways, timing and controls of hydrocarbon leakage (Anka et al., 2013; Ostanin et al., 2013). This is driven by the need to include focused fluid flow from different sources including pore water and diagenetic fluids. Similarly to petroleum systems, we can associate each fluid plumbing system to a specific source. In the Eastern Mediterranean, we describe the different plumbing systems that combine in two main areas: the Levant-Nile-Herodotus (Fig. 12A), and the Cyprus-Latakia area (Fig. 12B). 
In the Levant-Nile-Herodotus area (Fig. 12a), the escape routes for trapped subevaporitic fluids are: 1) laterally through the edges of the evaporites 2) vertically across evaporites. In the first case, the pinch-out of the Messinian evaporites is the focus of moatforming deformation and dissolution (Allen et al., 2016; Bertoni and Cartwright, 2005) and this causes the progressive basinward retreat of the lateral locus of seepage of subevaporitic ascending fluids (Fig. 2 and 12). In the second case, vertical fluid flow occurs across thick, tabular and relatively homogeneous evaporites, without dissolution collapse structure or welds. This suggests that overpressure is needed to create the necessary focused flow of fluids and sediments and lead to hydrofracturing and conduit formation. In this context, the lateral drainage is inhibited by lithological/structural discontinuities in the source deposits, and the ascending fluids are trapped beneath the evaporites, leading to overpressure build-up (Warren, 2016).

In this area, we observe pulses of focused fluid migration from the late Miocene to the Holocene, with peaks in the late Miocene, late Pliocene and Holocene. The fluids follow new columnar pathways (such as the mud volcanoes in the Nile Deep System) or exploit areas of structural weakness in existing discontinuities (such as the strike-slip faults in the southern Levant Basin). For fluid flow features that have a supra-evaporitic source, or develop where there are no evaporites, a feedback effect among fluid circulation, evaporite dissolution and deformation can enhance pathways and create dissolution moats at the edges of the evaporitic basin, or collapse crater above salt diapirs. In summary, the Levant Basin and Nile Cone plumbing systems (Figure 12A) presents the longest-lived record of focused fluid expulsion, and the areas with the most protracted history and most extreme cases of overpressure release (e.g. Kirkham et al., 2017) are located in the Nile Cone.

The Eratosthenes Block constitutes a stand-alone plumbing system within this area, due to its peculiar structural and stratigraphic evolution. A long-lived carbonate platform, deposited since the Cretaceous (Robertson et al., 1996; Robertson, 1998) acts as a lateral escape route for the pore fluids in surrounding deep basin areas, through the hydraulic connection of basinal clastic sedimentary units with the platform. Furthermore, a strong 
structural control is exercised by deep faults bordering the Eratosthenes block, and by the compression related to the Nile-Levant sedimentary wedge buttressing against the block. These factors led to the development of mostly vertical and highly focused flow features in the area of maximum deformation, in particular at the border with the Herodotus and Levant Basin.

In the Cyprus and Latakia area (Fig. 12B), the distribution of vertical vs lateral fluid pathways is strongly dependent on evaporite thickness and deformation. The tectonic history of the region shows that at the beginning of evaporite deposition, the basins were already structured, creating the depocentres that mostly still correspond to the present-day loci of maximum evaporite thickness. The continuous deformation of the basin, from the Miocene up to Recent, had a double-fold effect on fluid migration: the creation of tectonically overpressured areas, and the establishment of pathways and foci, such as structural highs and evaporite pinch-out, for fluids of deep origin. While in the Cyprus basin a deep, subevaporitic source of fluids is identified, this is not the case for the Latakia Basin. In this basin, the focused fluid flow evidence collected is only recent. The main pathways for fluid migration are represented by salt tectonics structures, including diapirs and intra-evaporite thrusts. Intra-evaporite flow is suggested by intra-evaporite crests spatially related to the seabed vertical fluid pathways. Overall, in this basin the fluid flow shows a lateral component, with the salt-cored thrusts and the diapirs controlling the wavelength of potential pressure cells, similar to what is observed in other salt giant basins worldwide such as the Northern Europe Permian Basin (Bjørlykke and Gran, 1994; Winefield et al., 2005).

\section{DISCUSSION}

This study shows that although fluid flow features are common in the Eastern Mediterranean, substantial differences can be observed in its various provinces. The characteristics of the fluid flow features are summarised below: 
- The spectrum of the fluid flow features covers pockmarks, pipes, mud volcanoes, clastic mounds, gas chimneys and collapse structures. Pockmarks, gas chimneys and pipes are ubiquitous in all basins. Mud volcanoes are observed in the Eratosthenes, Levant and Nile areas. The extent of the associated vertical fluid pathways varies from a few to several hundreds of meters, transecting large sections of stratigraphy. The highest-reaching features are located in the Nile and Levant areas.

- The timing of the focused fluid flow varies according to the area: from the late Miocene (Nile Cone and Levant Basin) through the Pliocene-Quaternary (Eratosthenes Block, and the Levant, Herodotus, Nile, Latakia and Cyprus Basins). In the HerodotusEratosthenes and Latakia basins, focused fluid flow is observed mostly at the seabed and therefore is dated as recent (Holocene). Earlier phases could have been overprinted by tectonic deformation, especially salt tectonics and are now no longer recognisable on the seismic data.

- Structural control is important at different levels: The migration and accumulation of fluid flow is strongly influenced by faults coupled with deep structural highs and evaporite deformation in the Herodotus-Eratosthenes, Latakia and partly in the Cyprus Basin.

- The fluids involved in the migration process can derive from different sources, including basin pore water, brines, hydrocarbons, diagenetic and deep crust/mantle fluids (Bjørlykke, 1993).

Overall, in the Eastern Mediterranean focused fluid flow is recorded through the past ca. 6 My of evolution of the basin, i.e. since the onset of the deposition of the Messinian evaporites. The focus of our analysis is on trying to understand the patterns in the distribution of these fluid flow features and ultimately if they can be used to unravel the fluid flow history of the basin. An important role in the fluid release events is potentially played by overpressure. Therefore, in order to discuss the mechanisms that create the fluid flow features, we first distinguish the features that are clearly linked to an overpressure fluid 
release event and subsequently, analyse their lateral and vertical distribution. Finally, we discuss their relationship to the MSC and evaporites.

\subsection{Mechanisms driving focused fluid flow}

Focused flow features document an anomaly to otherwise continuous and compaction related vertical and lateral fluid flow typically described in marine sedimentary basins (Bethke, 1986; Bjørlykke, 1993; Harrison and Summa, 1991). This extremely slow compaction-related flow is directly linked to porosity reduction in the sediments with burial, and it occurs in the shallow part of sedimentary basins, where fluid expulsion is correlated with increasing effective stress with burial, and very minor overpressure build-up occurs. Conversely, focused fluid flow is characterised by an intermittent flux, related to (often very rapid) fluid and sediment expulsion, and fracturing in the overburden (Deville et al., 2003; Deville and Guerlais, 2009). Most of the fluid flow features observed worldwide are related to the sudden release of overpressured fluids and hydrofracturing (Morley, 2003; Stewart and Davies, 2006).

However, morphologically similar, pipe-like geometries that are related to fluids, but not necessarily to overpressure, have been also widely reported. Typical examples include karstic terranes, where collapse chimneys or pipes can form as a result of the depletion of limestones and evaporites, by an undersaturated corrosive fluid (Anderson, 1981; Sun et al., 2013). Surficial subcircular features such as dolines form through this mechanism, and they usually cap a deeply rooted conduit created by the collapse of the overburden into the void of the dissolved mass (Stewart, 1999).

In the Eastern Mediterranean, a small number of mid-late Pliocene vertical fluid pathways can be ascribed to this mechanism (Bertoni and Cartwright, 2005; Eruteya et al., 2015). In these cases, the conduit itself is not generated by hydrofracturing. However, in the case described by Bertoni and Cartwright (2005), the corrosive subjacent fluids are thought to be sourced by the release of overpressured pore water from high-porosity sediment pockets 
within the pre-evaporitic canyon fill. This particular example of collapse feature is therefore also linked with overpressure release. Additionally, in the study area a number of cases of collapse features are directly associated with the crests of underlying diapirs (such as in the Latakia basin). In this case, the conduits are associated to collapse of the overburden due to preferential removal of the shallower remobilised evaporites, through dissolution or evacuation, as commonly observed in evaporite provinces worldwide (Warren, 2006).

\subsection{Role of overpressure and Messinian evaporites}

The majority of the fluid flow features in the Eastern Mediterranean are sourced from above the evaporites and they seem to constitute a mainly supra-evaporitic fluid flow system. however, from recent drilling results and modelling studies (Al-Balushi et al., 2016), it is known that overpressures are present in the sub-evaporite sequences. This suggests that the evaporites are an efficient seal the majority of the time, dividing two stacked pressure systems in the form of a supra-evaporite and sub-evaporite regime.

As previously mentioned, the identification and interpretation of a sub-evaporitic source is particularly challenging, as the loss of seismic resolution within the evaporitic package leads to poor imaging of both the conduit and the lower termination of possible vertical fluid pathways. Moreover, in the case of features associated with sediment remobilisation, the source of sediment can be different from the source of fluids. It is likely that as seismic data acquisition and processing techniques quality improve, together with the increased availability of 3D seismic datasets, many more of these cross-evaporitic features will be identified.

It is notable that of the small percentage of the fluid flow features that are certainly sourced from below the Messinian evaporites, most are located in the Nile-LevantEratosthenes areas. Among the fluid flow features that cross the Messinian evaporites, mud volcanoes are the primary examples in a number of locations of the Eastern Mediterranean. Mascle et al. (2014) observed that in the north-western Egyptian continental margin, mud volcanoes occur in an area where there is a thick Messinian evaporite cover, as opposed to 
the rest of the Mediterranean Basin, where these features are normally associated with an absence of subsurface evaporites. This is confirmed by Kirkham et al. (2017a), who described a long-lived system of mud volcanoes, occurring in this area of the Nile cone, from the end of the Messinian Salinity Crisis to the present day. This system is sourced in the immediately pre-evaporitic sediments. Additionally, our study shows that there are examples of mud volcanoes with a source located below the evaporites also in the Herodotus basin (Fig. 6), in the southern Levant Basin (Netzeband et al., 2006). Although these are only a minority of the fluid flow features observed in the entire study area, they are important because they show that extreme focused fluid release events are capable of piercing through the thick series of evaporites. Overpressures are known to play a fundamental role in remobilising fluids and sediments in the genesis of mud volcanoes. Therefore, overpressures in pre-evaporitic sediments play a role in sourcing the mud volcanoes and part of the fluid flow features that are observed to breach the evaporites.

In the Nile Delta area, abnormally high formation pressures have been recorded during hydrocarbon exploration (Dolson et al., 2005; Dolson et al., 2014; Dolson et al., 2001; Nashaat, 1998). Overpressures in the thick, clay-dominated Oligocene to Recent sedimentary section, and in the underlying pre-Tertiary section are primarily compactiondriven and due to rapid sedimentation (Nashaat, 1998). On the other hand, thermally-driven forces can also play a role in the abrupt build-up of pore pressures in the southern part of the Nile Delta, through aquathermal expansion and hydrocarbon generation or cracking of oil to gas in the lower Miocene-upper Oligocene sediments (Nashaat, 1998).

A recent study of the Levant Basin petroleum system (Al-Balushi et al., 2016) models pore pressures and predicts overpressure occurrence in the Eocene sediments due to their low permeability. The rapidity of loading and unloading is here considered as a major potential factor contributing to the creation of overpressures in the basin. A particularly important phase of rapid loading and subsidence is identified in the Oligo-Miocene, when deep-water turbidites were transported into the basin by the Nile system (Al-Balushi et al., 2016; Steinberg et al., 2011). Furthermore, during the MSC, the combination of pressure 
drop from the water unloading, the fast deposition of evaporites, and the pressure increase during the following water loading and sea-level rise are thought to play a major role in overpressure development, and release, in the sediments immediately preceding the evaporites (Bertoni and Cartwright 2015; Al Balushi et al 2016; Kirkham et al., 2017a). This would affect hydrocarbons already generated and in place at that time, and phase changes could happen depending on their composition (Al Balushi et al 2016). Previous studies quantify the relevance of the water level drop and erosion as causes of overpressure, and conclude that water level drops can result in significant fluid ovepressuring (Hermanrud et al., 2013). Although gas is not a necessary agent in the process, its presence has the potential to significantly enhance overpressures (Arntsen et al., 2007; Hermanrud et al., 2013). Quantifying the exact amount of overpressures generated across the different areas of the Eastern Mediterranean, from an extreme sea-level change and erosional phase such as the ones happened during the deposition of the Messinian evaporites, could hold the key for understanding the focused fluid release episodes that have been recorded in the late Miocene-early Pliocene Levant and Nile areas.

Tectonic stress, faulting and folding can also lead to seal breaching, either directly through the creation of the conduit for fluids, or through creation of overpressures (Luo, 2011; Luo and Vasseur, 1996; Luo et al., 2007; Neuzil, 1995; Nordgård Bolås et al., 2005; Unruh et al., 1992). This mechanism has been recorded in several foldbelts worldwide (Luo et al., 2007; Morley et al., 2014; Tingay et al., 2009), and although previously unreported, it is particularly likely to have acted in the northern part of the study area (Cyprus and Latakia basins, and the northern part of the Levant-Herodotus Basins), where the subduction zone causes an increase in lateral compression due to tectonic stress. The long-term development of the Syrian Arc foldbelt in most of the eastern part of the study area should also be considered as a possible mechanism for tectonic overpressure creation, and for subsequent release as a trigger of focused fluid flow from the crest of the anticline structures. 
In summary, the influence of the Messinian evaporites and of the MSC on focused fluid release in the Eastern Mediterranean Basin acted on different levels, which can be summarised as follows:

- The deposition of the evaporites in itself, as a nearly impermeable unit, has the potential of trapping earlier fluids inhibiting their normal compaction-related pore fluid release. Intra-evaporite clastic sediments can create tightly sealed reservoirs.

- Where the focused fluid features formed during the deposition of the Messinian evaporites, it is suggested that the loading - unloading processes associated to the crisis acted as a trigger in the overpressure release events, causing venting (in the Levant basin) or large scale mud volcanism (in the Nile area) (Bertoni and Cartwright, 2015; Kirkham et al., 2017b).

- In basins deformed by salt-tectonics, these structures played a fundamental role in creating migration pathways and remobilising overpressured fluids (Warren, 2016).

Evaporites can act as both a membrane and hydraulic seal (Watts, 1987). In the case of membrane seal, the thickness is not a controlling factor as capillary leakage is mediated by intrinsic properties of the rock. The properties of evaporites as hydraulic seal are dependent on thickness and are controlled by overpressure build-up. Highly focused fluid features, such as mud volcanoes, relate to this second type of seal, as the main mechanism forming the conduit is by hydrofracturing. Fluids appear to be able to cross the evaporites only in their most extreme expression, i.e. in near-lithostathic overpressure conditions (Schléder et al., 2008).

This is confirmed by our observations made in the Eastern Mediterranean, where in the presence of relatively undisturbed evaporites, cross-evaporite vertical fluid pathways are only observed at the high end of the flux-pressure range, and involve sediment remobilisation. In these predisposing conditions, overpressure release can be triggered as a consequence of slow build-up or by fast, extreme events. In the Nile Delta, the evaporite seal may locally act as a secondary mechanism of overpressure creation, while the primary 
mechanism would still be led by the high subsidence rate, sedimentary load (Factor 3 in Fig. 12B) from the Nile system and a thick, clay-dominated sedimentary section (Al-Balushi et al., 2016; Nashaat, 1998). Conversely, where evaporites are particularly thick and the Nilederived sedimentary sequence is thinner, the evaporite seal would become of primary importance (Factor 1 in Fig. 12B). Furthermore, the influence of sediment erosion and unloading during the deposition of the Messinian evaporites, and the marginal deformation of the evaporites and creation of salt welds would be greatest in the marginal areas of the basin (Factor 2 in Fig. 12B).

\section{CONCLUSIONS}

Our synthesis provides an updated record of the evidence of focused fluid flow in the Eastern Mediterranean, which includes recent and past occurrences through the last ca. 6 My of evolution of the basin. We do this by adding the interpretation of a previously unpublished regional 2D seismic dataset to the existing occurrences of focused fluid flow reported in the literature. Our interpretation shows a high number (141) of focused fluid flow features, which span the stratigraphic interval from late Miocene to Recent. Of these features, (89) are at the seabed, and (52) are buried. The spectrum of the features covers pockmarks, pipes, mud volcanoes, clastic intrusions and collapse structures.

The analysis of the upper terminus of the fluid flow features reveals the timing of the fluid expulsion events. The Levant and Nile Basins show the longest-lived record of focused fluid flow release, which happens intermittently from the late Miocene to recent. The Cyprus Basin also shows evidence of Pliocene focused flow release, while in the Eratosthenes and Latakia areas only recent episodes of venting were identified. The morphostructure of the conduits and thus, of the migration routes, is locally controlled by tectonic structures: strike-

slip faults in the Levant basin, deep crestal culminations in the Eratosthenes Block, salt/compressional tectonics in the Cyprus-Latakia Basins. 
Fluids (and associated remobilised sediments) are sourced from different intervals, from the sub- and supra-evaporitic section, and possibly within the evaporites. Sources include petroleum fluids, water and diagenetic fluids. Only a minor proportion of the fluid flow features that are able to cross the thick basinal evaporites are certainly sourced from subevaporitic sediments and fluids, and are mostly located in the Nile-Levant-Eratosthenes areas.

The influence of the Messinian evaporites and of the MSC in basin fluid dynamics is therefore threefold: 1) The deposition of the evaporites in itself, as a nearly impermeable unit, traps earlier fluids inhibiting their normal compaction-related pore fluid release. Intraevaporite clastics can create tightly sealed reservoirs and brine pockets; 2) Where the focused fluid features formed during the deposition of the Messinian evaporites, loading unloading processes associated to the MSC acted as a trigger in the overpressure release events, causing venting (in the Levant Basin) or large scale mud volcanism (in the Nile area). 3) In basins deformed by salt-tectonics, these structures played a fundamental role in creating migration pathways and remobilising overpressured fluids.

In conclusion, the few examples of pathways that are able to cross thick, undeformed and well preserved evaporites are typically correlated to overpressure release and hydrofracturing. Fluids appear to be able to cross the evaporites only in their most extreme expression, i.e. in near-lithostatic overpressure conditions. A specific combination of evaporite seal and Nile sediment load (possibly accompanied by sea-level change and water loading/unloading triggers) can play a large role in the release of sub-evaporitic overpressured pockets from the Pliocene to Recent. This is confirmed by our observations made in the Eastern Mediterranean, where in the presence of relatively undisturbed evaporites, cross-evaporite vertical fluid pathways are only observed at the high end of the flux-pressure range, and involve sediment remobilisation. 


\section{ACKNOWLEDGEMENTS}

We are grateful to SpectrumGeo for the permission to publish the seismic lines. CB thanks Shell for funding her research position at the University of Oxford. Schlumberger is gratefully acknowledged for the use of Petrel interpretation software. This paper substantially benefited from the thorough review and suggestions for improvements made by three anonymous reviewers. 


\section{REFERENCES}

Aal, A.A., El Barkooky, A., Gerrits, M., Meyer, H., Schwander, M., Zaki, H., 2000. Tectonic evolution of the Eastern Mediterranean Basin and its significance for hydrocarbon prospectivity in the ultradeepwater of the Nile Delta. The Leading Edge 19, 1086-1102.

Al-Balushi, A.N., Neumaier, M., Fraser, A.J., Jackson, C.A., 2016. The impact of the Messinian salinity crisis on the petroleum system of the Eastern Mediterranean: a critical assessment using 2D petroleum system modelling. Petroleum Geoscience 22, 357-379.

Allen, H., Jackson, C.A.-L., Fraser, A.J., 2016. Gravity-driven deformation of a youthful saline giant: the interplay between gliding and spreading in the Messinian basins of the Eastern Mediterranean. Petroleum Geoscience 22, 340-356.

Aloisi, G., Pierre, C., Rouchy, J.-M., Foucher, J.-P., Woodside, J., 2000. Methane-related authigenic carbonates of eastern Mediterranean Sea mud volcanoes and their possible relation to gas hydrate destabilisation. Earth and Planetary Science Letters 184, 321-338.

Anderson, R.Y., 1981. Deep-seated salt dissolution in the Delaware Basin, Texas and New Mexico. Environmental geology and hydrology in New Mexico: New Mexico Geological Society Special Publication 10, 133-145.

Anderson, R.Y., Kirkland, D.W., 1980. Dissolution of salt deposits by brine density flow. Geology 8, 66-69.

Andresen, K.J., 2012. Fluid flow features in hydrocarbon plumbing systems: What do they tell us about the basin evolution? Marine Geology 332-334, 89-108.

Anka, Z., Ondrak, R., Kowitz, A., Schødt, N., 2013. Identification and numerical modelling of hydrocarbon leakage in the Lower Congo Basin: Implications on the genesis of km-wide seafloor mounded structures. Tectonophysics 604, 153-171.

Arntsen, B., Wensaas, L., Løseth, H., Hermanrud, C., 2007. Seismic modeling of gas chimneys. Geophysics 72, 251-259.

Bayon, G., Loncke, L., Dupré, S., Caprais, J.-C., Ducassou, E., Duperron, S., Etoubleau, J., Foucher, J.P., Fouquet, Y., Gontharet, S., 2009. Multi-disciplinary investigation of fluid seepage on an unstable margin: the case of the Central Nile deep sea fan. Marine Geology 261, 92-104.

Bein, A., Gvirtzman, G., 1977. A Mesozoic fossil edge of the Arabian plate along the Levant coastline and its bearing on the evolution of the eastern Mediterranean. Structural History of the Mediterranean Basins. Technip, Paris, 95-110.

Ben-Avraham, Z., Schattner, U., Lazar, M., Hall, J., Ben-Gai, Y., Neev, D., Reshef, M., 2006. Segmentation of the Levant continental margin, eastern Mediterranean. Tectonics 25.

Bertello, F., Harby, H., Brandolese, S., 2016. Egypt: Zohr, an outstadning gas discovery in a new deepwater hydrocarbon play. 8th Mediterranean Offshore Conference and Exhibition, 19-21th April 2016. Bertoni, C., Cartwright, J., 2015. Messinian evaporites and fluid flow. Marine and Petroleum Geology 66, 165-176.

Bertoni, C., Cartwright, J., Hermanrud, C., 2013. Evidence for large-scale methane venting due to rapid drawdown of sea level during the Messinian Salinity Crisis. Geology 41, 371-374.

Bertoni, C., Cartwright, J.A., 2005. 3D seismic analysis of circular evaporite dissolution structures, Eastern Mediterranean. Journal of the Geological Society 162, 909-926.

Bertoni, C., Cartwright, J.A., 2006. Controls on the basinwide architecture of late Miocene (Messinian) evaporites on the Levant margin (Eastern Mediterranean). Sedimentary Geology 188189, 93-114.

Bertoni, C., Cartwright, J.A., 2007. Major erosion at the end of the Messinian Salinity Crisis: evidence from the Levant Basin, Eastern Mediterranean. Basin Research 19, 1-18.

Bethke, C.M., 1986. Inverse hydrologic analysis of the distribution and origin of Gulf Coast-type geopressured zones. Journal of Geophysical Research: Solid Earth 91, 6535-6545.

Bjørlykke, K., 1993. Fluid flow in sedimentary basins. Sedimentary Geology 86, 137-158. 
Bjørlykke, K., Gran, K., 1994. Salinity variations in North Sea formation waters: implications for largescale fluid movements. Marine and Petroleum Geology 11, 5-9.

Bowman, S.A., 2011. Regional seismic interpretation of the hydrocarbon prospectivity of offshore Syria. GeoArabia 16, 95-124.

Buchbinder, B., Zilberman, E., 1997. Sequence stratigraphy of Miocene-Pliocene carbonatesiliciclastic shelf deposits in the eastern Mediterranean margin (Israel): Effects of eustasy and tectonics. Sedimentary Geology 112, 7-32.

Camerlenghi, A., Cita, M., 1987. Setting and tectonic evolution of some Eastern Mediterranean deepsea basins. Marine geology 75, 31-55.

Camerlenghi, A., Cita, M.B., Hieke, W., Ricchiuto, T., 1992. Geological evidence for mud diapirism on the Mediterranean Ridge accretionary complex. Earth and Planetary Science Letters 109, 493-504. Cartwright, J., Huuse, M., Aplin, A., 2007. Seal bypass systems. AAPG Bulletin 91, 1141-1166. Cartwright, J., Santamarina, C., 2015. Seismic characteristics of fluid escape pipes in sedimentary basins: implications for pipe genesis. Marine and Petroleum Geology 65, 126-140.

Cartwright, J.A., Jackson, M.P.A., 2008. Initiation of gravitational collapse of an evaporite basin margin: The Messinian saline giant, Levant Basin, eastern Mediterranean. Bulletin of the Geological Society of America 120, 399-413.

Charlou, J., Donval, J., Zitter, T., Roy, N., Jean-Baptiste, P., Foucher, J., Woodside, J., Party, M.S., 2003. Evidence of methane venting and geochemistry of brines on mud volcanoes of the eastern Mediterranean Sea. Deep Sea Research Part I: Oceanographic Research Papers 50, 941-958. Cita, M.B., 2006. Exhumation of Messinian evaporites in the deep-sea and creation of deep anoxic brine-filled collapsed basins. Sedimentary Geology 188-189, 357-378.

Cita, M.B., Woodside, J.M., Ivanov, M., Kidd, R.B., Limonov, A.F., 1994. Fluid venting, mud volcanoes and mud diapirs in the Mediterranean Ridge. Rendiconti Lincei 5, 159-169.

Clark, I.R., Cartwright, J.A., 2009. Interactions between submarine channel systems and deformation in deepwater fold belts: Examples from the Levant Basin, Eastern Mediterranean sea. Marine and Petroleum Geology 26, 1465-1482.

Davison, I., 2009. Faulting and fluid flow through salt. Journal of the Geological Society 166, 205-216. Demaison, G., Huizinga, B.J., 1991. Genetic Classification of Petroleum Systems (1). AAPG bulletin 75, 1626-1643.

Deville, E., Battani, A., Griboulard, R., Guerlais, S., Herbin, J.P., Houzay, J.P., Muller, C., Prinzhofer, A., 2003. The origin and processes of mud volcanism: New insights from Trinidad, Geological Society Special Publication, pp. 475-490.

Deville, E., Guerlais, S.-H., 2009. Cyclic activity of mud volcanoes: evidences from Trinidad (SE Caribbean). Marine and Petroleum Geology 26, 1681-1691.

Dimitrov, L., Woodside, J., 2003. Deep sea pockmark environments in the eastern Mediterranean. Marine Geology 195, 263-276.

Dolson, J., Boucher, P., Siok, J., Heppard, P., 2005. Key challenges to realizing full potential in an emerging giant gas province: Nile Delta/Mediterranean offshore, deep water, Egypt, Geological Society, London, Petroleum Geology Conference series. Geological Society of London, pp. 607-624. Dolson, J.C., Atta, M., Blanchard, D., Sehim, A., Villinski, J., Loutit, T., Romine, K., 2014. Egypt's future petroleum resources: a revised look into the 21st century.

Dolson, J.C., Shann, M.V., Matbouly, S., Harwood, C., Rashed, R., Hammouda, H., 2001. AAPG Memoir 74, Chapter 23: The Petroleum Potential of Egypt.

Downey, M.W., 1984. Evaluating seals for hydrocarbon accumulations. AAPG Bulletin 68, 1752-1763. Druckman, Y., Buchbinder, B., Martinotti, G., Tov, R.S., Aharon, P., 1995. The buried Afiq Canyon (eastern Mediterranean, Israel): a case study of a Tertiary submarine canyon exposed in Late Messinian times. Marine Geology 123, 167-185.

Dupré, S., Woodside, J., Klaucke, I., Mascle, J., Foucher, J.-P., 2010. Widespread active seepage activity on the Nile Deep Sea Fan (offshore Egypt) revealed by high-definition geophysical imagery. Marine Geology 275, 1-19. 
Eruteya, O.E., Waldmann, N., Schalev, D., Makovsky, Y., Ben-Avraham, Z., 2015. Intra-to postMessinian deep-water gas piping in the Levant Basin, SE Mediterranean. Marine and Petroleum Geology 66, 246-261.

Esestime, P., Hewitt, A., Hodgson, N., 2016. Zohr-A newborn carbonate play in the Levantine Basin, East-Mediterranean. First Break 34, 87-93.

Feng, Y.E., Yankelzon, A., Steinberg, J., Reshef, M., 2016. Lithology and characteristics of the Messinian evaporite sequence of the deep Levant Basin, eastern Mediterranean. Marine Geology 376, 118-131.

Frey-Martinez, J., Cartwright, J., Hall, B., Huuse, M., 2007. Clastic intrusion at the base of deep-water sands: A trap-forming mechanism in the eastern Mediterranean.

Fuhrmann, A., Weimer, P., Bouroullec, R., Pettingill, H., Gardosh, M., Hurst, A., 2010. Origin of Lower Pliocene remobilized deepwater mounded deposits, Yafo Formation, Levant Basin, and southeastern Mediterranean: A head-scratching group exercise to explain mounded deposits, Seismic imaging of depositional and geomorphic systems: 30th Annual GCCSEPM Foundation Annual Bob F. Perkins Research Conference Proceedings. SEPM, pp. 482-502.

Gardosh, M.A., Druckman, Y., 2006. Seismic stratigraphy, structure and tectonic evolution of the Levantine Basin, offshore Israel. Geological Society, London, Special Publications 260, 201-227. Gardosh, M.A., Garfunkel, Z., Druckman, Y., Buchbinder, B., 2010. Tethyan rifting in the Levant Region and its role in Early Mesozoic crustal evolution. Geological Society, London, Special Publications 341, 9-36.

Gardosh, M.A., Tannenbaum, E., 2014. The petroleum systems of Israel.

Garfunkel, Z., 1998. Constrains on the origin and history of the Eastern Mediterranean basin. Tectonophysics 298, 5-35.

Garfunkel, Z., 2004. Origin of the Eastern Mediterranean basin: a reevaluation. Tectonophysics 391, 11-34.

Garfunkel, Z., Derin, B., 1984. Permian-early Mesozoic tectonism and continental margin formation in Israel and its implications for the history of the Eastern Mediterranean. Geological Society, London, Special Publications 17, 187-201.

Gaullier, V., Mart, Y., Bellaiche, G., Mascle, J., Vendeville, B.C., Zitter, T., Benkhelil, J., Buffet, G., Droz, L., Ergun, M., Huguen, C., Kopf, A., Levy, R., Limonov, A., Shaked, Y., Volkonskaia, A., Woodside, J., 2000. Salt tectonics in and around the Nile deep-sea fan: Insights from the PRISMED II cruise, Geological Society Special Publication, pp. 111-129.

Ghanbarzadeh, S., Hesse, M.A., Prodanović, M., Gardner, J.E., 2015. Deformation-assisted fluid percolation in rock salt. Science 350, 1069-1072.

Giresse, P., Loncke, L., Huguen, C., Muller, C., Mascle, J., 2010. Nature and origin of sedimentary clasts associated with mud volcanoes in the Nile deep-sea fan. Relationships with fluid venting. Sedimentary Geology 228, 229-245.

Gluyas, J., Swarbrick, R., 2009. Petroleum geoscience. John Wiley \& Sons.

Gradmann, S., Hübscher, C., Ben-Avraham, Z., Gajewski, D., Netzeband, G., 2005. Salt tectonics off northern Israel. Marine and Petroleum Geology 22, 597-611.

Harrison, W.J., Summa, L.L., 1991. Paleohydrology of the Gulf of Mexico Basin. Americal Journal of Science 291, 109-176.

Hawie, N., Gorini, C., Deschamps, R., Nader, F.H., Montadert, L., Granjeon, D., Baudin, F., 2013. Tectono-stratigraphic evolution of the northern Levant Basin (offshore Lebanon). Marine and Petroleum Geology 48, 392-410.

Hempton, M.R., 1987. Constraints on Arabian plate motion and extensional history of the Red Sea. Tectonics 6, 687-705.

Hermanrud, C., Venstad, J.M., Cartwright, J., Rennan, L., Hermanrud, K., Bolås, H.M.N., 2013. Consequences of water level drops for soft sediment deformation and vertical fluid leakage. Mathematical Geosciences 45, 1-30. 
Hovland, M., Judd, A.G., 1988. Seabed pockmarks and seepages: impact on geology, biology and the marine environment. Seabed pockmarks and seepages: impact on geology, biology and the marine environment.

Hovland, M., Rueslåtten, H., Johnsen, H., Kvamme, B., Kuznetsova, T., 2006. Salt formation associated with sub-surface boiling and supercritical water. Marine and Petroleum Geology 23, 855869.

Hsu", K.J., 1972. Origin of saline giants: A critical review after the discovery of the Mediterranean Evaporite. Earth-Science Reviews 8, 371-396.

Hübscher, C., Dümmong, S., 2011. Levant Basin - salt and fluid dynamics. Mem. Soc. Geol. Fr. Atlas of Messinian seismic markers in the Mediterranean and Black Seas, 72.

Hübscher, C., Tahchi, E., Klaucke, I., Maillard, A., Sahling, H., 2009. Salt tectonics and mud volcanism in the Latakia and Cyprus Basins, eastern Mediterranean. Tectonophysics 470, 173-182.

Huguen, C., Foucher, J.-P., Mascle, J., Ondréas, H., Thouement, M., Gontharet, S., Stadnitskaia, A., Pierre, C., Bayon, G., Loncke, L., 2009. Menes caldera, a highly active site of brine seepage in the Eastern Mediterranean sea: "in situ" observations from the NAUTINIL expedition (2003). Marine Geology 261, 138-152.

Huguen, C., Mascle, J., Chaumillon, E., Woodside, J.M., Benkhelil, J., Kopf, A., Volkonskaïa, A., 2001. Deformational styles of the eastern Mediterranean Ridge and surroundings from combined swath mapping and seismic reflection profiling. Tectonophysics 343, 21-47.

Hunt, J.M., 1990. Generation and migration of petroleum from abnormally pressured fluid compartments (1). AAPG bulletin 74, 1-12.

Judd, A.G., Hovland, M., 2007. Seabed Fluid Flow : The Impact on Geology, Biology and the Marine Environment. Cambridge University Press, Cambridge.

Kastens, K.A., Spiess, F., 1984. Dissolution and collapse features on the Eastern Mediterranean Ridge. Marine Geology 56, 181-193.

Kirkham, C., Cartwright, J., Hermanrud, C., Jebsen, C., 2017a. The genesis of mud volcano conduits through thick evaporite sequences. Basin Research.

Kirkham, C., Cartwright, J., Hermanrud, C., Jebsen, C., 2017b. The spatial, temporal and volumetric analysis of a large mud volcano province within the Eastern Mediterranean. Marine and Petroleum Geology 81, 1-16.

Kopf, A., Robertson, A., Clennell, M., Flecker, R., 1998. Mechanisms of mud extrusion on the Mediterranean Ridge Accretionary Complex. Geo-Marine Letters 18, 97-114.

Kopf, A., Robertson, A., Volkmann, N., 2000. Origin of mud breccia from the Mediterranean Ridge accretionary complex based on evidence of the maturity of organic matter and related petrographic and regional tectonic evidence. Marine Geology 166, 65-82.

Kukla, P., Reuning, L., Becker, S., Urai, J., Schoenherr, J., 2011. Distribution and mechanisms of overpressure generation and deflation in the late Neoproterozoic to early Cambrian South Oman Salt Basin. Geofluids 11, 349-361.

Lazar, M., Lang, G., Schattner, U., 2016. Coincidence or not? Interconnected gas/fluid migration and ocean-atmosphere oscillations in the Levant Basin. Geo-Marine Letters 36, 293-306.

Lazar, M., Schattner, U., Reshef, M., 2012. The great escape: An intra-Messinian gas system in the eastern Mediterranean. Geophysical Research Letters 39.

Limonov, A.F., Woodside, J.M., Cita, M.B., Ivanov, M.K., 1996. The Mediterranean Ridge and related mud diapirism: a background. Marine Geology 132, 7-19.

Lofi, J., Déverchère, J., Gaullier, V., Gillet, H., Gorini, C., Guennoc, P., Loncke, L., Maillard, A., Sage, F., Thinon, I., 2011. Seismic atlas of the Messinian Salinity Crisis markers in the Mediterranean and Black Seas. Société Géologique de France.

Loncke, L., Gaullier, V., Mascle, J., Vendeville, B., Camera, L., 2006. The Nile deep-sea fan: An example of interacting sedimentation, salt tectonics, and inherited subsalt paleotopographic features. Marine and Petroleum Geology 23, 297-315. 
Loncke, L., Mascle, J., 2004. Mud volcanoes, gas chimneys, pockmarks and mounds in the Nile deepsea fan (Eastern Mediterranean): Geophysical evidences. Marine and Petroleum Geology 21, 669689.

Løseth, H., Wensaas, L., Arntsen, B., Hanken, N.-M., Basire, C., Graue, K., 2011. 1000 m long gas blow-out pipes. Marine and Petroleum Geology 28, 1047-1060.

Luo, X., 2011. Simulation and characterization of pathway heterogeneity of secondary hydrocarbon migration. AAPG Bulletin 95, 881-898.

Luo, X., Vasseur, G., 1996. Geopressuring mechanism of organic matter cracking: numerical modeling. AAPG bulletin 80, 856-873.

Luo, X., Wang, Z., Zhang, L., Yang, W., Liu, L., 2007. Overpressure generation and evolution in a compressional tectonic setting, the southern margin of Junggar Basin, northwestern China. AAPG bulletin 91, 1123-1139.

Lykousis, V., Alexandri, S., Woodside, J., De Lange, G., Dählmann, A., Perissoratis, C., Heeschen, K., loakim, C., Sakellariou, D., Nomikou, P., 2009. Mud volcanoes and gas hydrates in the Anaximander mountains (Eastern Mediterranean Sea). Marine and Petroleum Geology 26, 854-872.

Macgregor, D.S., 2012. The development of the Nile drainage system: integration of onshore and offshore evidence. Petroleum Geoscience 18, 417-431.

Maillard, A., Hübscher, C., Benkhelil, J., Tahchi, E., 2011. Deformed Messinian markers in the Cyprus Arc: tectonic and/or Messinian Salinity Crisis indicators? Basin Research 23, 146-170.

Marlow, L., 2014. Tectonostratigraphic History and Petroleum Potential of the Levantine Basin, Eastern Mediterranean.

Mart, Y., Ryan, W.B., Lunina, O.V., 2005. Review of the tectonics of the Levant Rift system: the structural significance of oblique continental breakup. Tectonophysics 395, 209-232.

Mascle, J., Mary, F., Praeg, D., Brosolo, L., Camera, L., Ceramicola, S., Dupré, S., 2014. Distribution and geological control of mud volcanoes and other fluid/free gas seepage features in the Mediterranean Sea and nearby Gulf of Cadiz. Geo-Marine Letters 34, 89-110.

McClusky, S., Balassanian, S., Barka, A., Demir, C., Ergintav, S., Georgiev, I., Gurkan, O., Hamburger, M., Hurst, K., Kahle, H., 2000. Global Positioning System constraints on plate kinematics and dynamics in the eastern Mediterranean and Caucasus. Journal of Geophysical Research: Solid Earth $105,5695-5719$.

Montadert, L., Nicolaides, S., Semb, P.H., Lie, Ø., 2014. Petroleum systems offshore Cyprus. Morley, C., 2003. Outcrop examples of mudstone intrusions from the Jerudong anticline, Brunei Darussalam and inferences for hydrocarbon reservoirs. Geological Society, London, Special Publications 216, 381-394.

Morley, C.K., Warren, J., Tingay, M., Boonyasaknanon, P., Julapour, A., 2014. Reprint of: Comparison of modern fluid distribution, pressure and flow in sediments associated with anticlines growing in deepwater (Brunei) and continental environments (Iran). Marine and petroleum geology 55, 230249.

Moss, J.L., Cartwright, J., 2010. 3D seismic expression of km-scale fluid escape pipes from offshore Namibia. Basin Research 22, 481-501.

Moss, J.L., Cartwright, J., Moore, R., 2012. Evidence for fluid migration following pockmark formation: Examples from the Nile Deep Sea Fan. Marine Geology 303-306, 1-13.

Nader, F.H., 2011. The petroleum prospectivity of Lebanon: an overview. Journal of Petroleum Geology 34, 135-156.

Nashaat, M., 1998. Memoir 70, Chapter 10: Abnormally High Formation Pressure and Seal Impacts on Hydrocarbon Accumulations in the Nile Delta and North Sinai Basins, Egypt.

Netzeband, G.L., Hübscher, C.P., Gajewski, D., 2006. The structural evolution of the Messinian evaporites in the Levantine Basin. Marine Geology 230, 249-273.

Neuzil, C., 1995. Abnormal pressures as hydrodynamic phenomena. American Journal of Science $295,742$. 
Nordgård Bolås, H.M., Hermanrud, C., Teige, G.M., 2005. Seal capacity estimation from subsurface pore pressures. Basin Research 17, 583-599.

Ostanin, I., Anka, Z., di Primio, R., Bernal, A., 2013. Hydrocarbon plumbing systems above the Snøhvit gas field: Structural control and implications for thermogenic methane leakage in the Hammerfest Basin, SW Barents Sea. Marine and Petroleum Geology 43, 127-146.

Praeg, D., Ketzer, J.M., Augustin, A.H., Migeon, S., Ceramicola, S., Dano, A., Ducassou, E., Dupré, S., Mascle, J., Rodrigues, L.F., 2014. Fluid seepage in relation to seabed deformation on the central Nile deep-sea fan, part 2: evidence from multibeam and sidescan imagery, Submarine Mass Movements and Their Consequences. Springer, pp. 141-150.

Prinzhofer, A., Deville, E., 2013. Origins of hydrocarbon gas seeping out from offshore mud volcanoes in the Nile delta. Tectonophysics 591, 52-61.

Reading, H.G., 1996. Sedimentary Environments: Processes, Facies and Stratigraphy. 3rd. Edition. Blackwell Science. Oxford.

Reiche, S., Hübscher, C., Beitz, M., 2014. Fault-controlled evaporite deformation in the Levant Basin, Eastern Mediterranean. Marine Geology 354, 53-68.

Reiche, S., Hübscher, C., Ehrhardt, A., 2015. The impact of salt on the late Messinian to recent tectonostratigraphic evolution of the Cyprus subduction zone. Basin Research.

Robertson, A., Dixon, J., 1984. Introduction: aspects of the geological evolution of the Eastern Mediterranean. Geological Society, London, Special Publications 17, 1-74.

Robertson, A., Dixon, J., Brown, S., Collins, A., Morris, A., Pickett, E., Sharp, I., Ustaömer, T., 1996. Alternative tectonic models for the Late Palaeozoic-Early Tertiary development of Tethys in the Eastern Mediterranean region. Geological Society, London, Special Publications 105, 239-263. Robertson, A.H., 1998. Mesozoic-Tertiary tectonic evolution of the easternmost Mediterranean area: integration of marine and land evidence. Proceedings of the Ocean Drilling Program, Scientific Results, Vol. 160; Chapter 54.

Robertson, A.H., Kopf, A., 1998. Tectonic setting and processes of mud volcanism on the Mediterranean Ridge accretionary complex: evidence from Leg 160. Proceedings of the Ocean Drilling Program, Scientific Results, Vol. 160; Chapter 50.

Rouchy, J.M., Caruso, A., 2006. The Messinian salinity crisis in the Mediterranean basin: a reassessment of the data and an integrated scenario. Sedimentary Geology 188, 35-67.

Roveri, M., Flecker, R., Krijgsman, W., Lofi, J., Lugli, S., Manzi, V., Sierro, F.J., Bertini, A., Camerlenghi, A., De Lange, G., Govers, R., Hilgen, F.J., Hübscher, C., Meijer, P.T., Stoica, M., 2014. The Messinian Salinity Crisis: Past and future of a great challenge for marine sciences. Marine Geology 352, 25-58. Roveri, M., Gennari, R., Lugli, S., Manzi, V., Minelli, N., Reghizzi, M., Riva, A., Rossi, M.E., Schreiber, B.C., 2016. The Messinian salinity crisis: open problems and possible implications for Mediterranean petroleum systems. Petroleum Geoscience 22, 283-290.

Ryan, W.B.F., 2009. Decoding the Mediterranean salinity crisis. Sedimentology 56, 95-136.

Sagy, Y., Gvirtzman, Z., Reshef, M., Makovsky, Y., 2015. The enigma of the Jonah high in the middle of the Levant basin and its significance to the history of rifting. Tectonophysics 665, 186-198.

Schattner, U., Lazar, M., Harari, D., Waldmann, N., 2012. Active gas migration systems offshore northern Israel, first evidence from seafloor and subsurface data. Continental Shelf Research 48, 167-172.

Schléder, Z., Urai, J.L., Nollet, S., Hilgers, C., 2008. Solution-precipitation creep and fluid flow in halite: a case study of Zechstein (Z1) rocksalt from Neuhof salt mine (Germany). International Journal of Earth Sciences 97, 1045-1056.

Schoenherr, J., Urai, J.L., Kukla, P.A., Littke, R., Schleder, Z., Larroque, J.-M., Newall, M.J., Al-Abry, N., Al-Siyabi, H.A., Rawahi, Z., 2007. Limits to the sealing capacity of rock salt: A case study of the infraCambrian Ara Salt from the South Oman salt basin. AAPG bulletin 91, 1541-1557.

Schofield, N., Alsop, I., Warren, J., Underhill, J.R., Lehné, R., Beer, W., Lukas, V., 2014. Mobilizing salt: Magma-salt interactions. Geology 42, 599-602. 
Scribano, V., Carbone, S., Manuella, F.C., Hovland, M., Rueslåtten, H., Johnsen, H.-K., 2017. Origin of salt giants in abyssal serpentinite systems. International Journal of Earth Sciences, 1-14.

Skiple, C., Anderson, E., Fürstenau, J., 2012. Seismic interpretation and attribute analysis of the Herodotus and the Levantine Basin, offshore Cyprus and Lebanon. Petroleum Geoscience 18, 433442.

Steinberg, J., Gvirtzman, Z., Folkman, Y., Garfunkel, Z., 2011. Origin and nature of the rapid late Tertiary filling of the Levant Basin. Geology 39, 355-358.

Stewart, S.A., 1999. Seismic interpretation of circular geological structures. Petroleum Geoscience 5, 273-285.

Stewart, S.A., Davies, R.J., 2006. Structure and emplacement of mud volcano systems in the South Caspian Basin. AAPG Bulletin 90, 771-786.

Sun, Q., Cartwright, J., Wu, S., Chen, D., 2013. 3D seismic interpretation of dissolution pipes in the South China Sea: Genesis by subsurface, fluid induced collapse. Marine Geology 337, 171-181.

Tibor, G., Ben-Avraham, Z., 1992. Late Tertiary seismic facies and structures of the Levant passive margin off central Israel, eastern Mediterranean. Marine Geology 105, 253-273.

Tingay, M.R., Hillis, R.R., Swarbrick, R.E., Morley, C.K., Damit, A.R., 2009. Origin of overpressure and pore-pressure prediction in the Baram province, Brunei. AAPG Bulletin 93, 51-74.

Unruh, J., Davisson, M., Criss, R., Moores, E., 1992. Implications of perennial saline springs for abnormally high fluid pressures and active thrusting in western California. Geology 20, 431-434.

Vidal, N., Alvarez-Marron, J., Klaeschen, D., 2000. Internal configuration of the Levantine Basin from seismic reflection data (eastern Mediterranean). Earth and Planetary Science Letters 180, 77-89.

Warren, J.K., 2006. Evaporites: Sediments, Resources and Hydrocarbons: Sediments, Resources, and Hydrocarbons. Springer.

Warren, J.K., 2016. Salt usually seals, but sometimes leaks: Implications for mine and cavern stability in the short and long term. Earth-Science Reviews.

Watts, N., 1987. Theoretical aspects of cap-rock and fault seals for single-and two-phase hydrocarbon columns. Marine and Petroleum Geology 4, 274-307.

Winefield, P., Gilham, R., Elsinger, R., 2005. Plumbing the depths of the Central Graben: towards an integrated pressure, fluid and charge model for the Central North Sea HPHT play, Geological Society, London, Petroleum Geology Conference series. Geological Society of London, pp. 1301-1315.

Woodside, J., Ivanov, M., Limonov, A., 1997. Neotectonics and fluid flow through seafloor sediments in the Eastern Mediterranean and Black Seas(preliminary results of geological and geophysical investigations during the ANAXIPROBE/TTR-6 cruise of R/V Gelendzhik, July-August 1996. Part I, Eastern Mediterranean Sea). Série technique- Unesco, Commission océanographique intergouvernementale.

Woodside, J., Ivanov, M., Limonov, A., 1998. Shallow gas and gas hydrates in the Anaximander Mountains region, eastern Mediterranean Sea. Geological Society, London, Special Publications 137, 177-193.

Ziegler, P.A., 2001. Peri-Tethyan Rift/Wrench Basins and Passive Margins. Publications scientifiques du Muséum. 


\section{FIGURE CAPTIONS}

Figure 1 A: Map of the Eastern Mediterranean, showing the study area, dataset and main tectonic elements from previous studies (Robertson, 1998; Tibor and Ben-Avraham, 1992; Vidal et al., 2000). Evidence of fluid flow features is compiled from this study (dots with black rim) and from previously published data (dots without black rim) (Bertoni and Cartwright, 2015; Bertoni and Cartwright, 2005; Bowman, 2011; Dupré et al., 2010; Eruteya et al., 2015; Frey-Martinez et al., 2007; Hübscher et al., 2009; Lazar et al., 2012; Loncke and Mascle, 2004; Mascle et al., 2014; Netzeband et al., 2006; Reiche et al., 2014). Bathymetry from EMODNET (http://www.emodnet.eu/). The numbers and the continuous red lines refer to the location of seismic lines shown in the figures. Red dashed line: boundary between Levant Herodotus Basins and Turkish or Eurasian plate according to Aal et al. (2000). Other basin boundaries are taken from references mentioned above. LB=Latakia Basin; CB: Cyprus Basin.

Figure 2 TWT thickness (isochron) map of the Messinian evaporites from this study. The filled black dots indicate the fluid flow features with cross-evaporitic conduit or sub-evaporitic source. The dashed black arrows indicate retreat of the evaporite pinch-out, due to dissolution and deformation (Allen et al., 2016; Bertoni and Cartwright, 2006; Loncke et al., 2006). The outline of the present-day pinch-out of the Messinian evaporites in the Nile Cone area is from Loncke et al. (2006). Explanation for other symbols in Fig. 1.

Figure 3 TWT thickness (isochron) map of the Plio-Quaternary overburden to the Messinian evaporites. The black dots indicate the fluid flow features (from this study) with buried upper termini, the white dots indicate fluid flow features that reach the seabed. Explanation for other symbols in Fig. 1.

Figure 4 Regional sections crossing the main sub-basins discussed in this study, and illustrating the different context (thickness, deformation) of the evaporite series. A: Regional 2D seismic section across the Levant and Herodotus Basins, separated by the Eratosthenes 
Block. B: Regional 2D seismic section across the Cyprus and Latakia Basins. TES: Top Erosional Surface (Top Messinian evaporites). BES: Base Erosional surface (Base Messinian evaporites). BMM: Base Mid Miocene.. SU: Senonian Unconformity. Location of seismic sections in Fig. 1.

Figure 5 A: Seismic section crossing the Southern Levant Basin. The black box highlights the zoomed section in Fig. 5B. The black lines and arrows indicate faults and folds associated to strike slip deformation in the area. SF: Seafloor. TES: Top Erosional Surface (Top Messinian evaporites). BES: Base Erosional surface (Base Messinian evaporites). BMM: Base Mid Miocene, TO: Top Oligocene. UE: Upper Eocene. UC: Upper Cretaceous B: Zoom showing a vertical conduit overlain by a sediment remobilisation edifice (clastic mound). M: mound. C: TWT seabed map from a nearby 3D seismic survey (Clark and Cartwright 2009). Location of the pipe and clastic intrusion in Fig. 5B is indicated by the black dot and the seismic line in Fig. 5A is indicated by the black line (outside 3D seismic coverage). Note the presence of nearby strike slip fault (red dashed lines). Location of seismic section in Fig. 1.

Figure 6 A: 3D seismic section from the Lebanon 3D seismic survey (courtesy of SpectrumGeo) crossing the Central Levant Basin and the stratigraphy of the Messinian evaporites (Bertoni and Cartwright, 2007; Lofi et al., 2011). This section shows a focused fluid flow feature at the base of the Messinian evaporites (BES) interpreted as a pockmark.. SF: Seafloor. TES: Top Erosional Surface (Top Messinian evaporites). BES: Base Erosional surface (Base Messinian evaporites). Location of seismic section in Fig. 1 and 6B. B: Variance extraction of BES showing the circular planform of the pockmarks.

Figure 7 A: Seismic section crossing the Herodotus Basin, showing the deformed evaporitic section and Pliocene-Quaternary overburden. B: Zoom showing the details of a mud volcano (MV), its boundaries highlighted by the dotted black line. SF: Seafloor. TES: Top Erosional 
Surface (Top Messinian evaporites). BES: Base Erosional surface (Base Messinian evaporites). TO: Top Oligocene. Location of seismic section in Fig. 1.

Figure 8 A: Seismic section crossing the Herodotus Basin at the edges of the Eratosthenes Block. B: Zoom showing the chimney associated with clastic intrusion. SF= seafloor. The dotted lines enclose the area of subvertical disrupted seismic character, which are overlain by high amplitude fringes and lensoidal reflection configuration. SF: Seafloor. TES: Top Erosional Surface (Top Messinian evaporites). BES: Base Erosional surface (Base Messinian evaporites). Location of seismic section in Fig. 1.

Figure 9 A: Seismic section crossing the Cyprus Basin B: Zoom showing the focused fluid flow feature interpreted as a mound related to clastic intrusion. Black arrows indicate onlap of reflections on to the mound. SF: Seafloor. TES: Top Erosional Surface (Top Messinian evaporites). BES: Base Erosional surface (Base Messinian evaporites). UC: Upper Cretaceous. Location of seismic section in Fig. 1.

Figure 10 Focused fluid flow features identified in the Cyprus Basin and interpreted as a pockmark (PM) overlying a deeply rooted pipe, below the MES (Margin Erosional Surface), and a mound overlying a clastic intrusion (CM), above the MES. Both features are highlighted by the rectangular black box. SF: Seafloor. TES: Top Erosional Surface (Top Messinian evaporites). BES: Base Erosional surface (Base Messinian evaporites). UC: Upper Cretaceous. Location of seismic section in Fig. 1.

Figure 11 Table summarising the main characteristics of the fluid flow features mapped in this study, which present sub-evaporitic source of fluids or sediments.

Figure 12 Summary diagram illustrating the different types and context of focused fluid flow features in the three main sub-basins of the Eastern Mediterranean, located within a representative cross-basinal section (Fig. 12A): The Nile and Levant (B) and Cyprus and Latakia (C). Refer to Figures 1 and 2 for location. Detailed processes explanation is given in body text. AA: amplitude anomaly; OP: overpressure, Cl: clastic intrusion; SF: seafloor, M: 
mound; PM: pockmark; MV: mud volcano. For Figure 12B: 1: distribution of evaporite load; 2: influence of marginal erosion and evaporite deformation; 3: distribution of Nile-derived sedimentary load. 


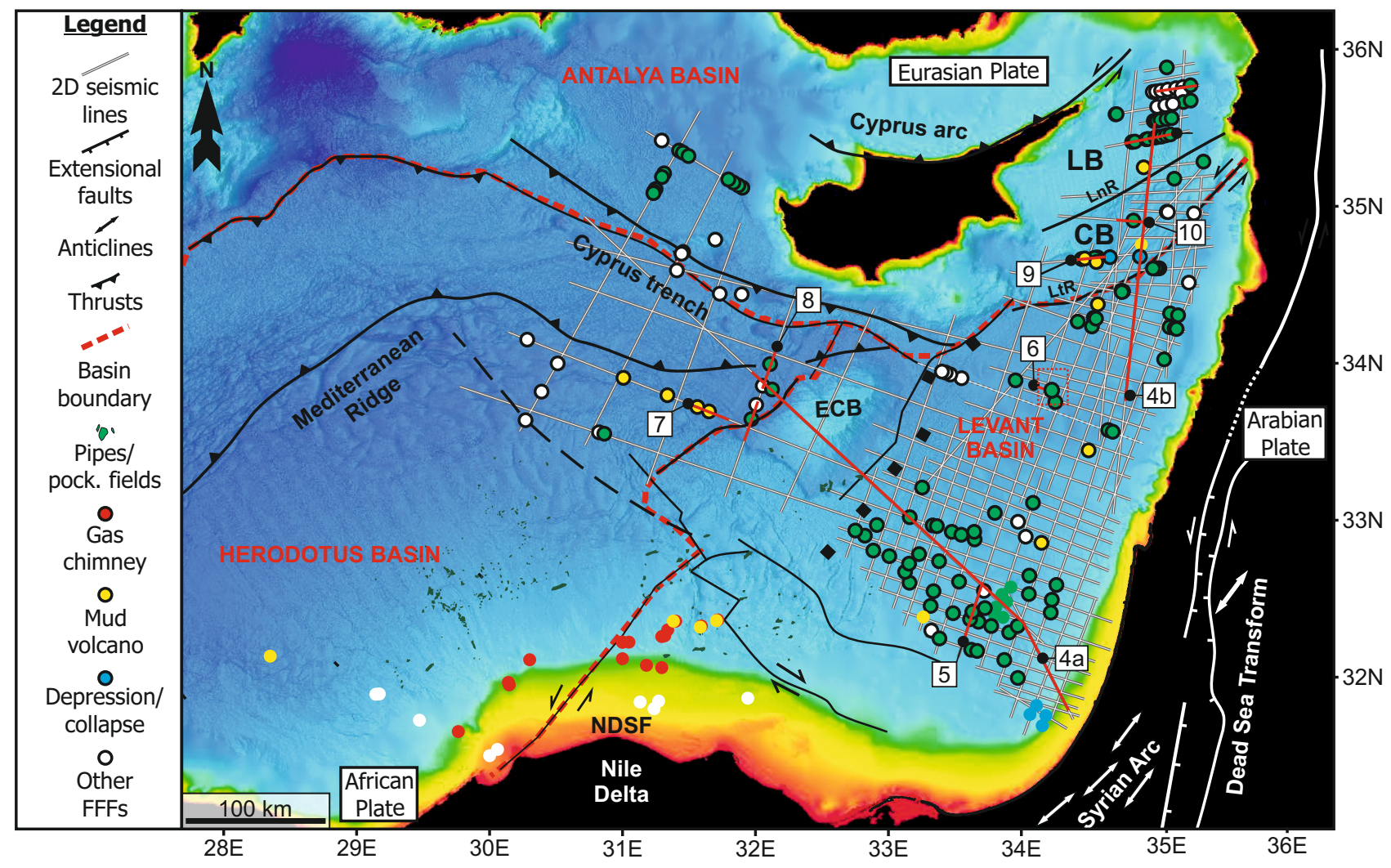

Figure 1 


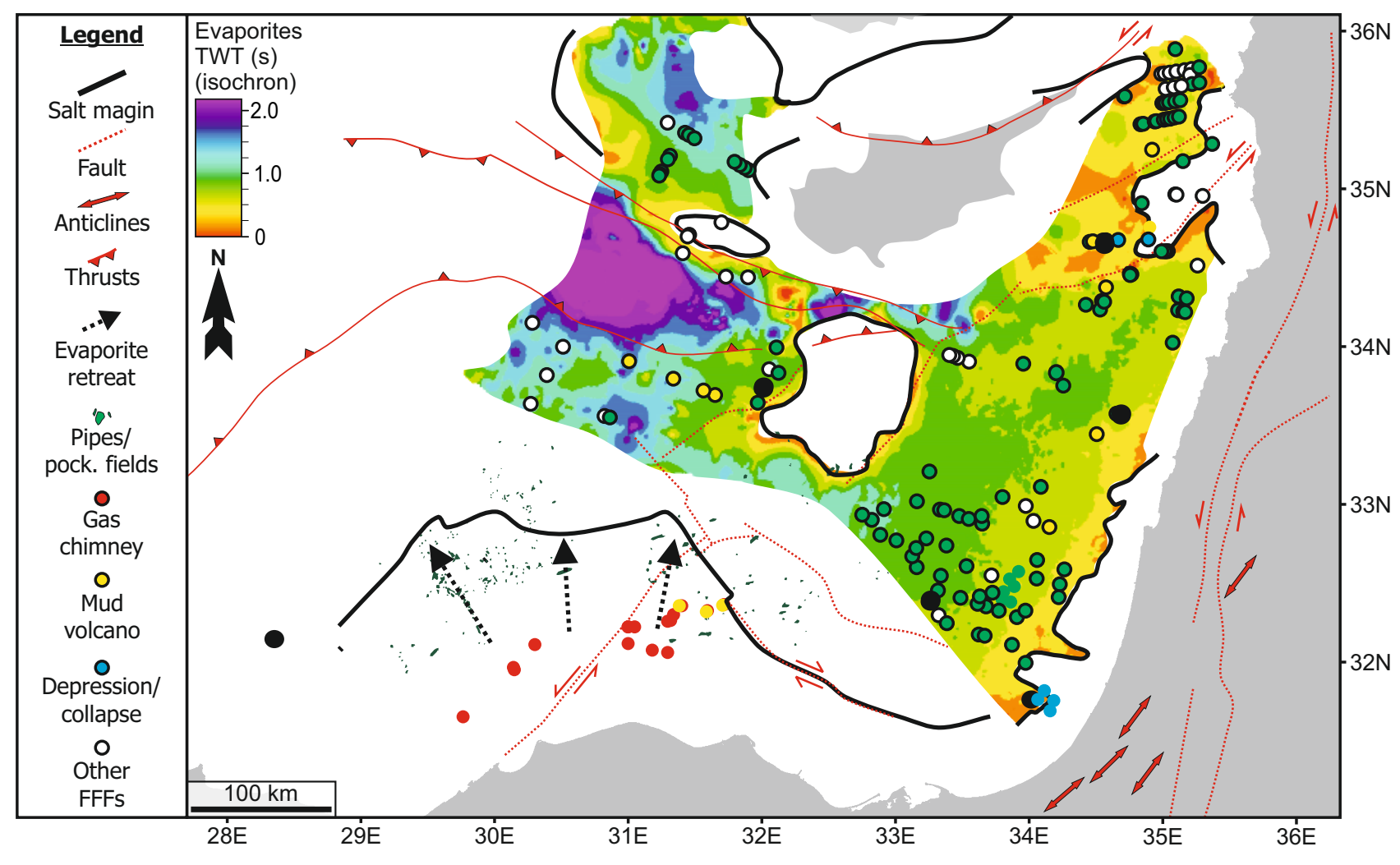

Figure 2 


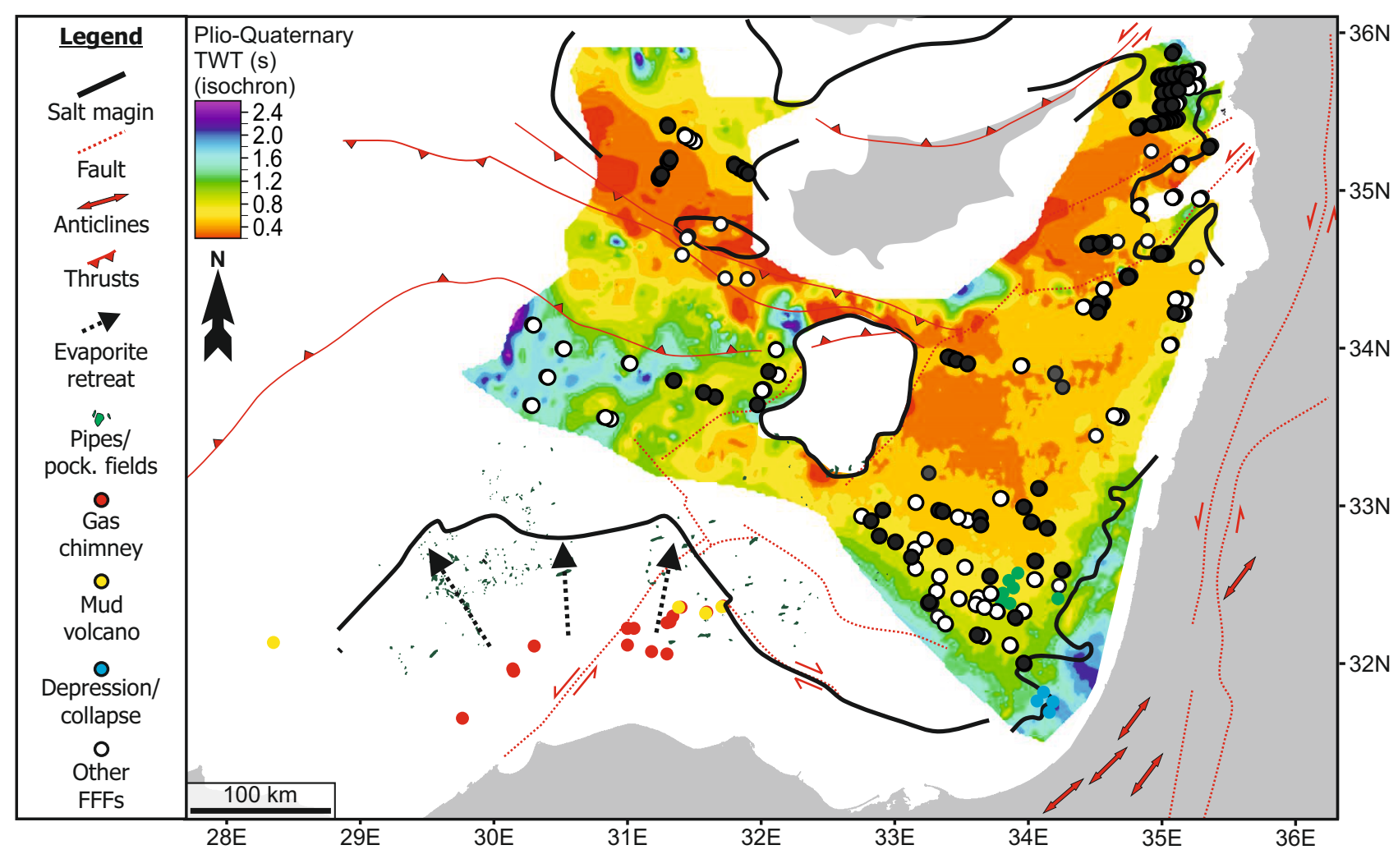

Figure 3 


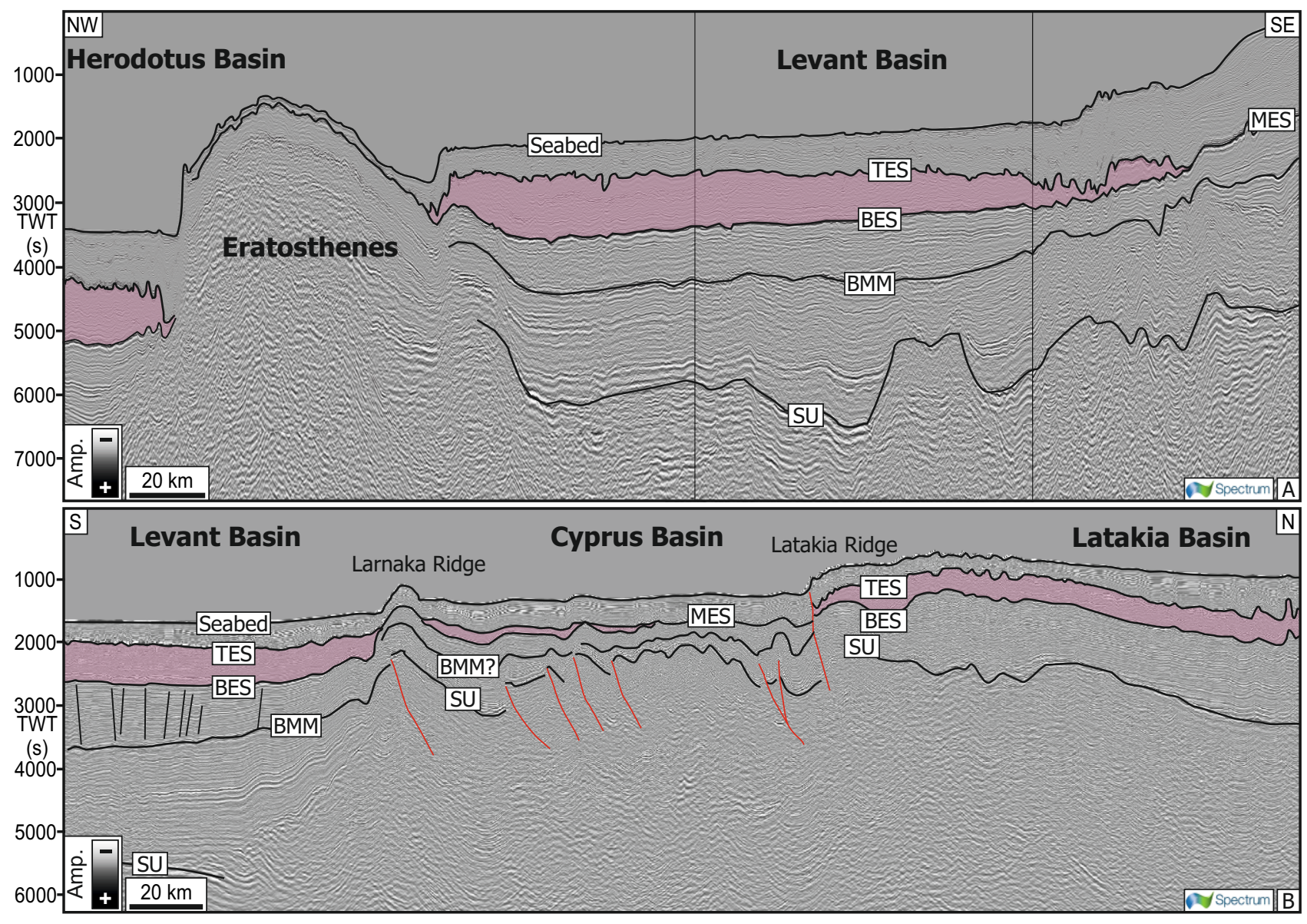

Figure 4 


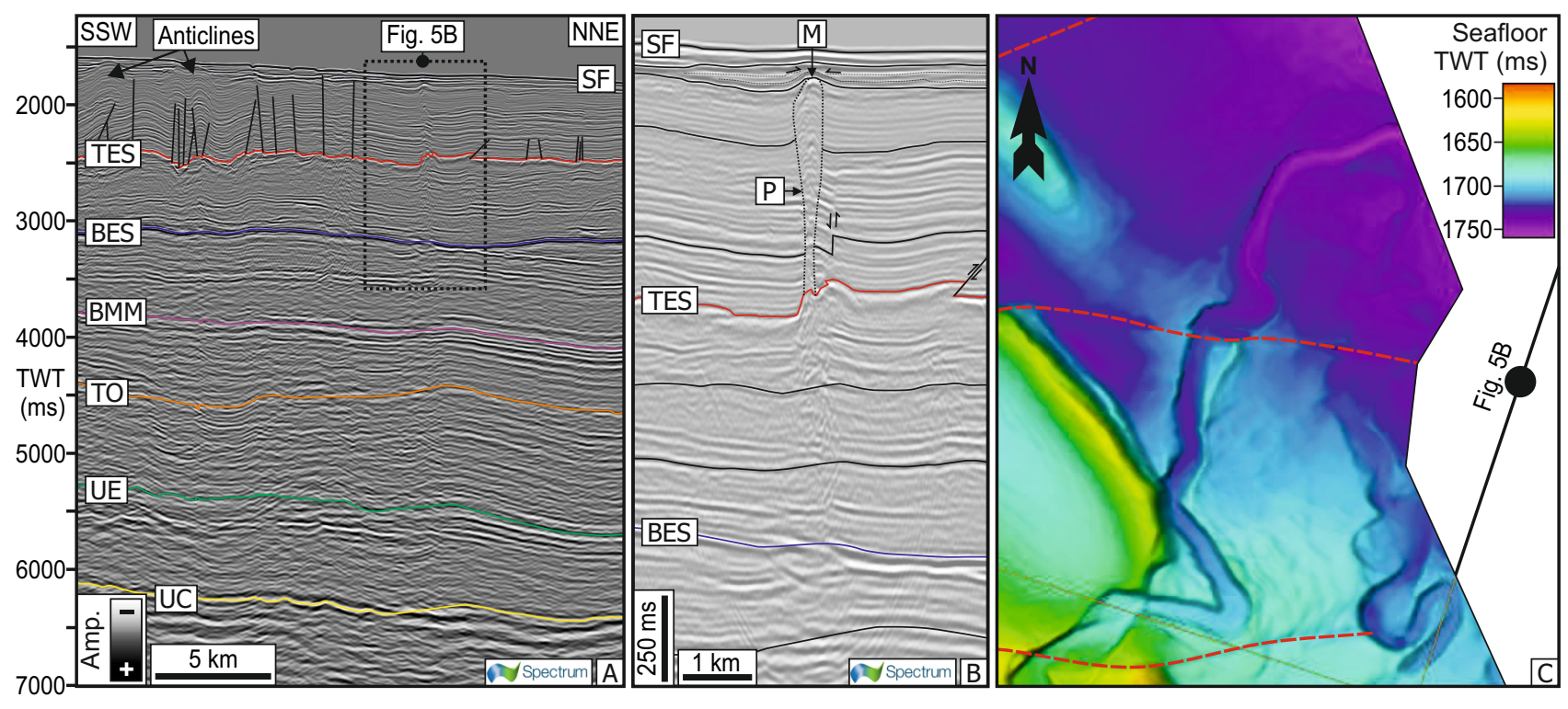

Figure 5 


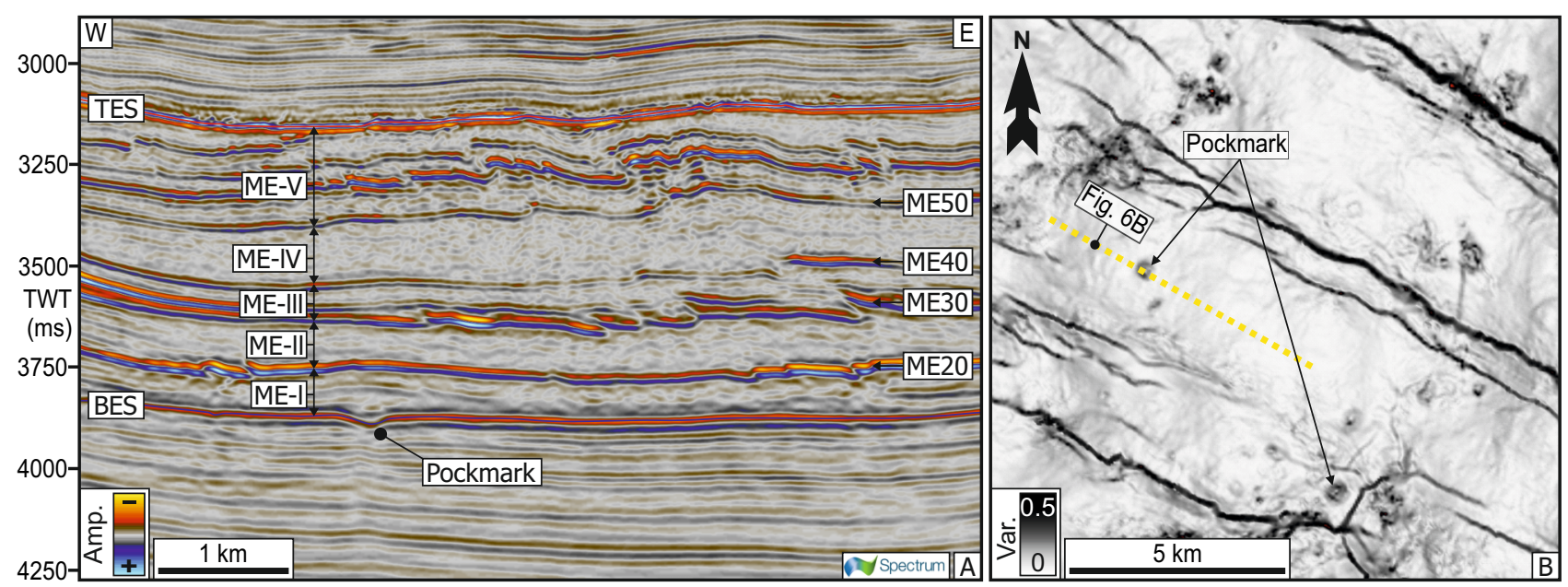

Figure 6 

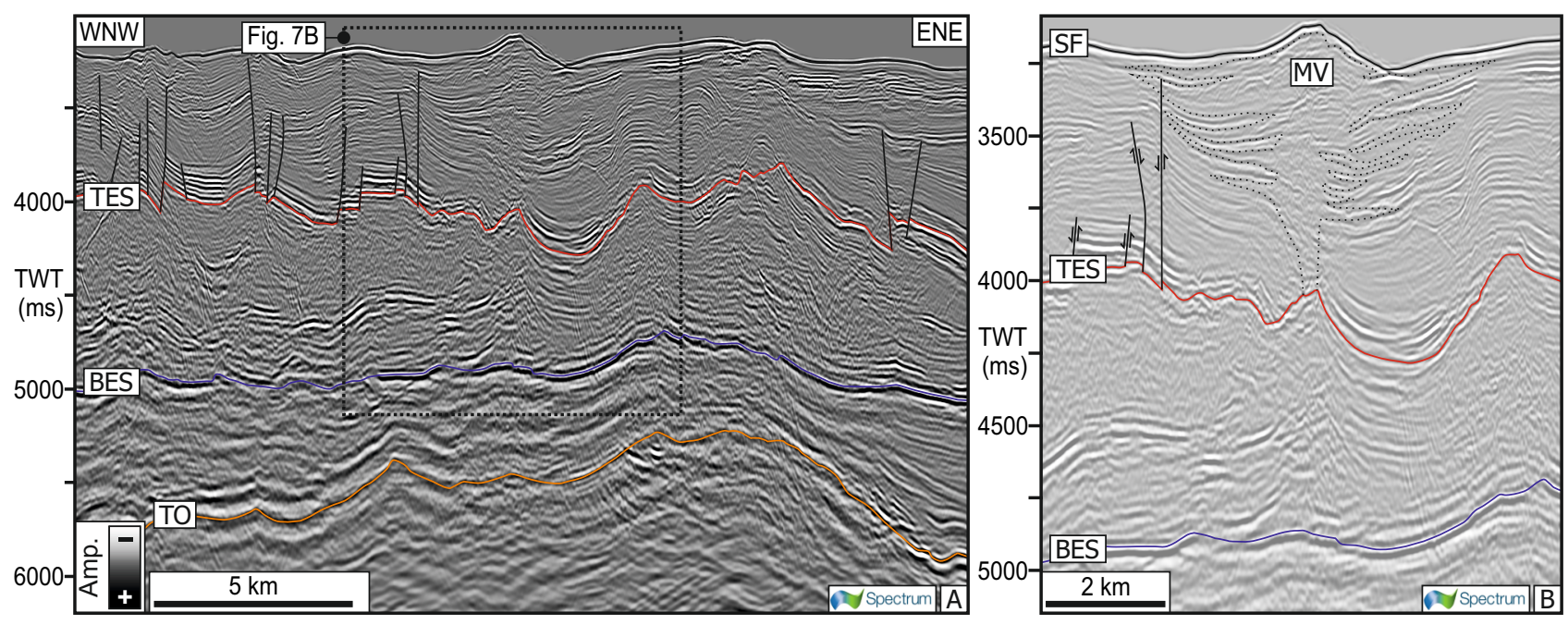

Figure 7 

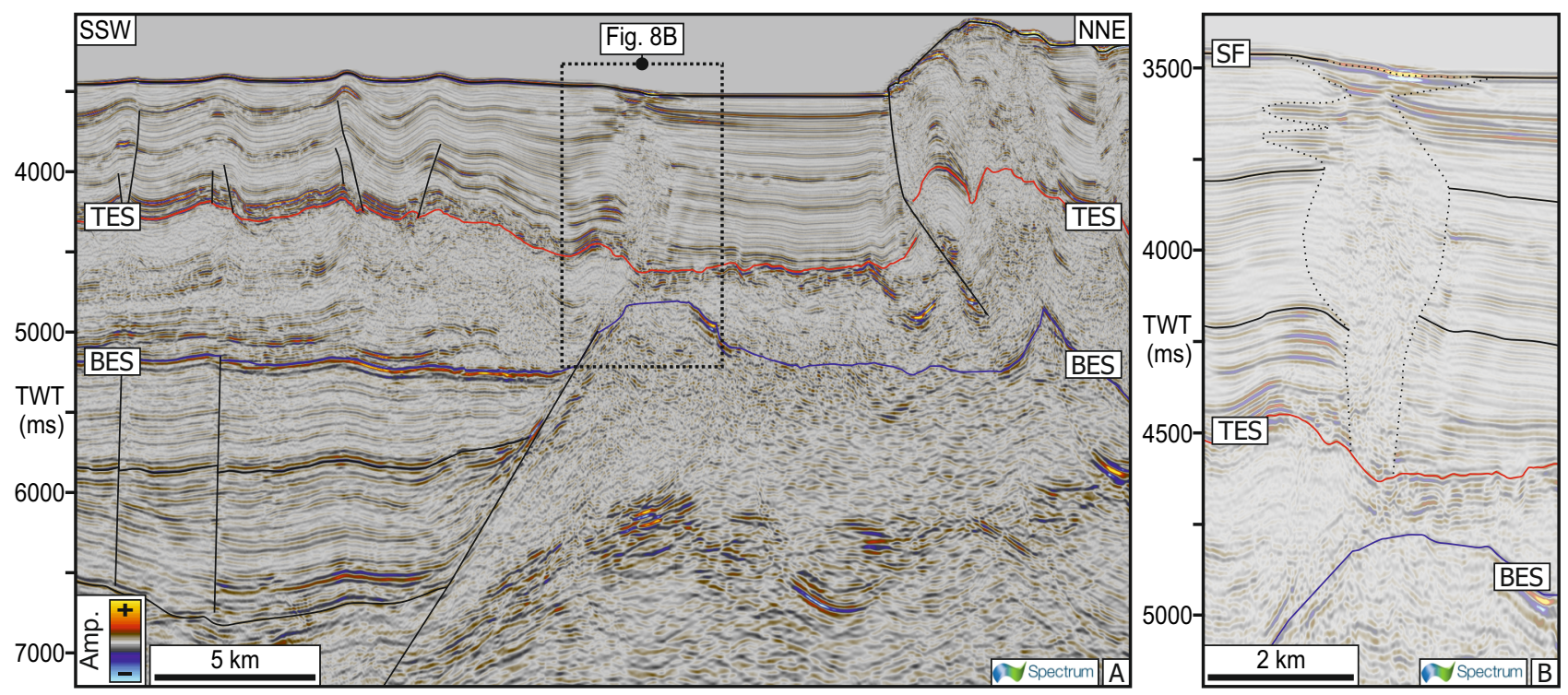

Figure 8 

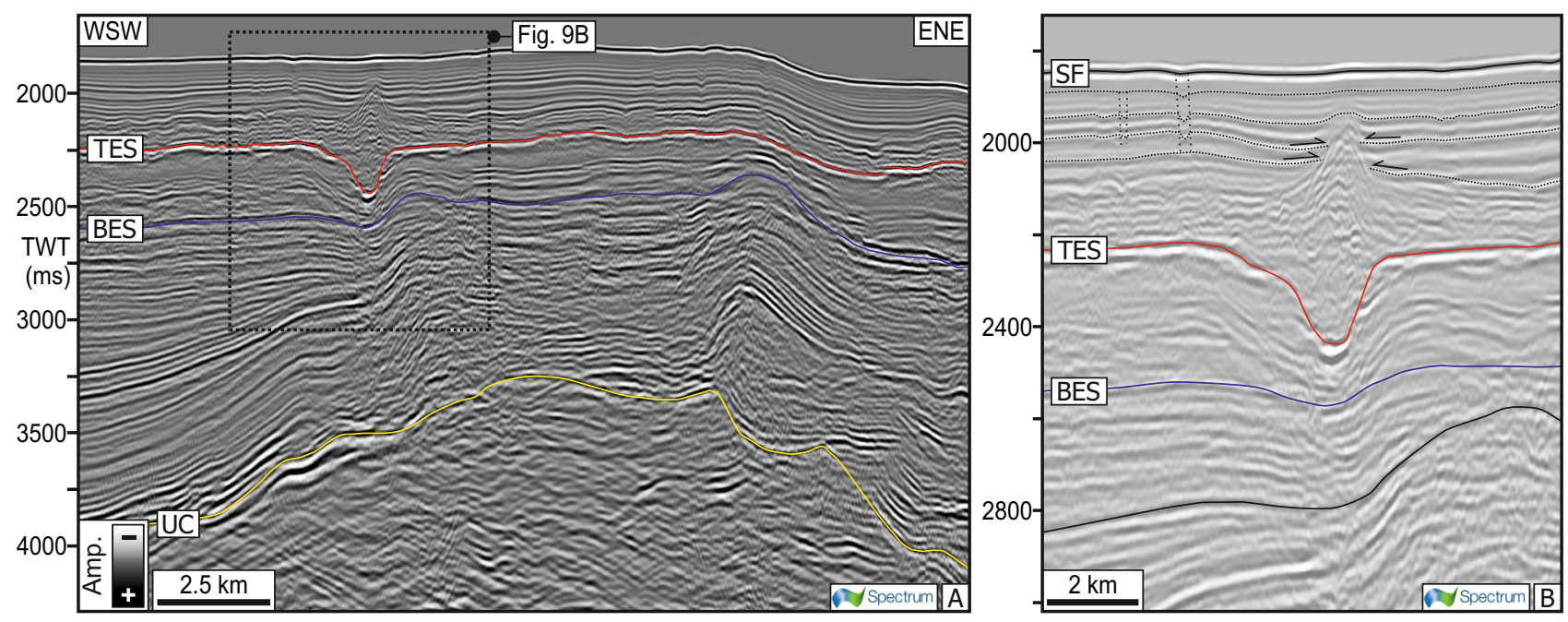

Figure 9 


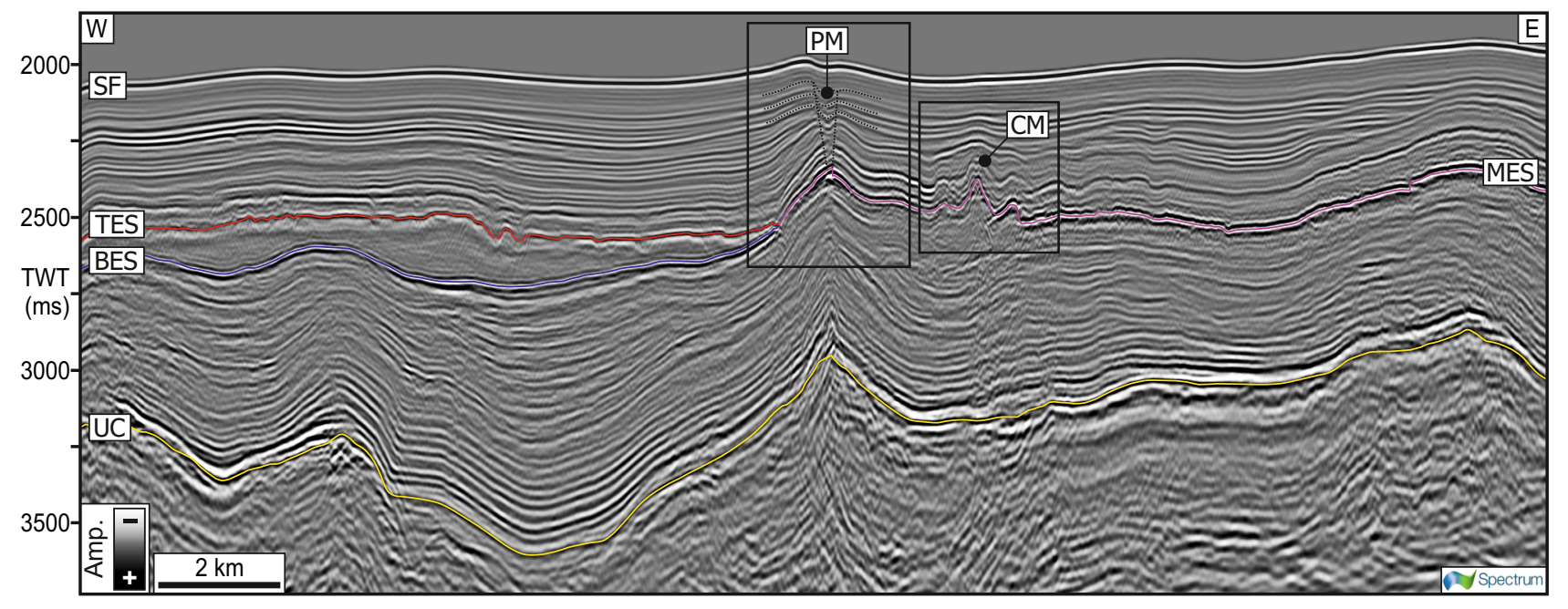

Figure 10 


\begin{tabular}{|l|l|l|l|}
\hline \multicolumn{5}{|c|}{ Fluid flow features with sub-evaporitic source } \\
\hline & Timing & Conduit & Type \\
\hline Levant 1 (Fig. 5) & Lower Quaternary & Cross-evaporitic and Plio-Quaternary clastics & Pipe and clastic intrusion \\
\hline Levant 2 (Fig. 6) & Late Miocene & Pre-evaporitic clastics (?) & Pockmark \\
\hline Eratosthenes 1 (Fig. 7) & Recent & Cross-evaporitic, and Plio-Quaternary clastics & Mud volcano \\
\hline Eratosthenes 2 (Fig. 8) & Recent & Cross-evaporitic and Plio-Quaternary clastics & Pipe and clastic intrusion \\
\hline Cyprus 1 (Fig. 9) & Pliocene & Cross-evaporitic and Plio-Quaternary clastics & Clastic intrusion \\
\hline Cyprus 2 (Fig. 10) & Recent & Pre-evaporites, MES and Plio-Quaternary clastics & Pipe and pockmark \\
\hline
\end{tabular}



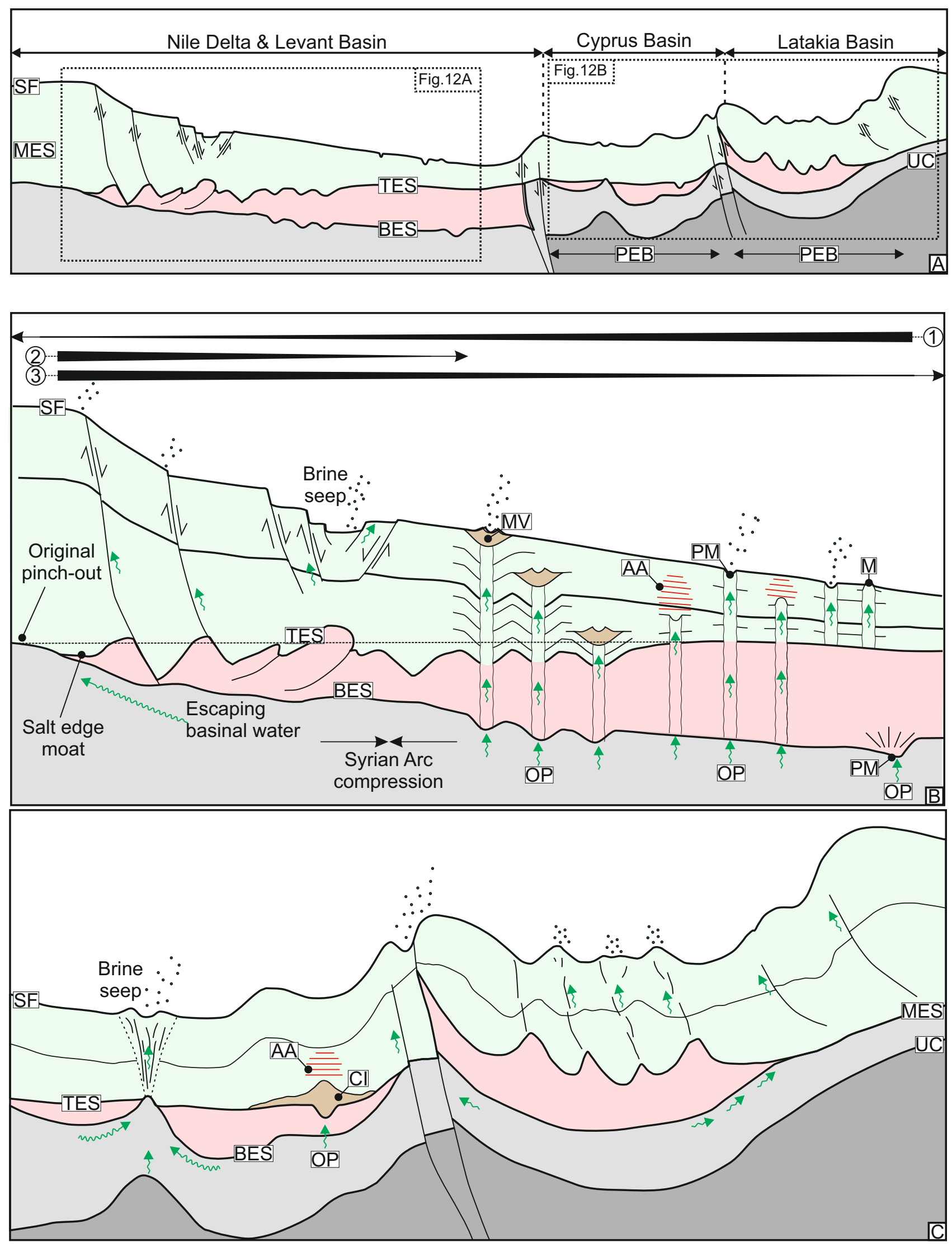

Figure 12 